\title{
ATTEMPT TO UNDERSTAND PUBLIC-HEALTH RELEVANT SOCIAL DIMENSIONS OF COVID-19 OUTBREAK IN POLAND
}

\author{
ANDRZEJ JARYNOWSKI ${ }^{1}$, MONIKA WÓJTA-KEMPA ${ }^{2}$, DANIEL PŁATEK ${ }^{3}$, \& KAROLINA \\ $\mathrm{CZOPEK}^{4}$
}

1 Interdisciplinary Research Institute, ul. Dolnobrzeska 17/2, 54-072 Wroclaw, Poland. System Modeling Group, Institute for Veterinary Epidemiology and Biostatistics, Freie Universität Berlin, Königsweg 67, 14163 Berlin, Germany. ORCID: 0000-0003-0949-6674, Email: ajarynowski@interdisciplinary-research.eu

${ }^{2}$ Wroclaw Medical University, Faculty of Health Science, Department of Public Health, ul. Bartla 5, 51618 Wrocław, Poland. ORCID: 0000-0002-0027-1033, Email: monika.wojta-kempa@umed.wroc.pl

${ }^{3}$ Polish Academy of Sciences, Institute of Political Studies, ul. Polna 18/20, 00-625 Warsaw, Poland. ORCID: 0000-0002-8253-3622, Email: dplatek21@gmail.com

${ }^{4}$ University of Warsaw, Institute of English Studies, ul. Hoża 69, 00-681 Warsaw, Poland. ORCID: 0000-0002-2165-7365, Email: karo.czopek@gmail.com

ABSTRACT: Recently, the whole of Europe, including Poland, have been significantly affected by COVID-19 and its social and economic consequences which are already causing dozens of billions of euros monthly losses in Poland alone. Social behaviour has a fundamental impact on the dynamics of the spread of infectious diseases such as SARS-CoV-2, challenging the existing health infrastructure and social organization. Modelling and understanding mechanisms of social behaviour (e.g. panic and social distancing) and its contextualization with regard to Poland can contribute to better response to the outbreak on a national and local level.

In the presented study we aim to investigate the impact of the COVID-19 on society by: (i) measuring the relevant activity in internet news and social media; (ii) analysing attitudes and demographic patterns in Poland. In the end, we are going to implement computational social science and digital epidemiology research approach to provide urgently needed information on social dynamics during the outbreak.

This study is an ad hoc reaction only, and our goal is to signal the main areas of possi- 
ble research to be done in the future and cover issues with direct or indirect relation to public health.

KEYWORDS: medical sociology, social distancing, social contact patterns, infectious disease epidemiology, SARS-CoV-2, media communication, risk perception, panic

\title{
INTRODUCTION
}

Social behaviour affects the dynamics of the spread of infectious diseases such as SARS-CoV-2 (virus), but these issues were very often omitted by medical researchers (Squazzoni, et al. 2020). The COVID-19 (disease) pandemic caused not only a massive, global health crisis, but also a reconfiguration of the established forms of social life. The virus contributes to profound disruptions in:

- economy - global shortages in product supply and falls in services, production and stock markets;

- society - possible occurrence of panic, restrictions on migration and participation in social events;

- culture - restriction of freedoms and stringent mitigation measures.

In a macro scale, mitigation strategies such as 'social distancing' and 'lock-down' entail high costs for the national economy and supply chains and are not easily sustainable in the long run. In contrast, in a micro-scale, they lead to various responses of individuals, from panic and fear to misinterpretation and disobedience (Sowada 2020). In the face of a pandemic, badly informed people tend to panic, which may lead to bad decision-making and/or high stress levels, causing anxiety or aggression (Frewer 1996). People who are not fully informed seek further information on the Internet, which is full of diverse content, but expert knowledge may not be easy to find and comprehend (Gonsalves, Staley 2019). In those circumstances, the lay networks arise as the main source of social norms. In this paper, we strive to explore the community perceptions and practices around COVID-19 in the context of Polish society.

The structure of the article is as follows: after presenting theoretical background from the fields of epidemiology and sociology, we analyse behaviour patterns and reactions to the epidemic (social mobilization and atomization, panic, information propagation, risk perception) with a particular focus on internet and demographic data. We also examine the specificity of the Polish context by studying responses to the present situation from various perspectives (sociolinguistics, demography, values and attitudes).

\begin{abstract}
AIM
Although most aspects of COVID-19 fall into the research area of medical science, social science researchers have not only data, resources and knowledge, but also a
\end{abstract}


professional and moral responsibility to contribute to broadening our understanding of this phenomenon (Sitek 2007). Therefore, we want to model and understand social mechanisms during the COVID-19 outbreak from an epidemiological and sociological perspective. To do so, we aim to investigate:

- the specificity of Polish society in terms of sociological and epidemiological aspects of COVID-19,

- the impact of COVID-19 on the society by measuring the relevant activity in internet news and social media (Jarynowski, Wójta-Kempa, Belik 2020A),

- the role of panic and behavioural change in case of an epidemic.

Moreover, we want to present a comprehensive perspective of empirical data and studies about Polish society relevant directly and indirectly to public health. The selection of content contained in this work is the result of treating public health as an interdisciplinary concept, aiming at “(...) preventing disease, prolonging life and promoting health through the organized efforts of society” (Acheston 1988). Only by coordinated actions of government and society, supported by many branches of sciences, can contemporary health problems be solved. We believe that this analysis could contribute to the improvement of the response to the epidemic on a national and local level via well-targeted information campaigns that take into consideration behavioural, demographic, cultural and other contexts.

\section{EPIDEMIOLOGICAL BACKGROUND}

On March 11th, 2020 the World Health Organisation declared the coronavirus outbreak a pandemic (WHO 2020), because European countries struggle to fight the disease. In Poland, virus infectivity (Jarynowski, Grabowski 2015) is moderate (natural $\mathrm{R}_{0} \sim 2.5$ (Worldometer 2020), explicit estimation based on positive tests $\mathrm{R}_{0}=3.1$ (Boch el. 2020), effective $\mathrm{R}_{0}=1.7$ (Interdisciplinary 2020C)) and mortality is low ( $<1 \%$ [Worldometer 2020]) in young and healthy populations (according to the current data up until the end of March).

The most important transmission routes of the virus are either direct (airborne), or indirect (through contact with contaminated surfaces). In most cases, the virus requires close contact over a longer time period to be transmitted (majority of infections occur in the same household or studying/working place). However, there are additional and less probable, but possible routes such as any indirect physical contact or even using items which were used by an infected person. Up until now (end of March 2020) there is no effective vaccine and no specific validated drug therapy against COVID-19 and there are epidemic outbreaks in all EU countries. So far, the only mitigation methods include:

- contact reduction (social distancing, e.g. isolation / quarantine, restrictions for travel or mass gatherings);

- reduction of the probability of infection transmission (e.g. standard precau- 
tions such as hand hygiene or immunomodulation such as 'healthy lifestyle');

- decreasing infectious period (e.g. testing, contact tracing, treatment).

In Poland the first case was officially confirmed on 04.03.2020 (ECDC 2020). Majority of the first 50 cases were imported (lack of epidemiological link on Fig. 1). Moreover, social distancing measures such as school closure (11.03), services closure (16.03) and significant mobility restriction (24.03) were announced.

At the same time, general guidelines from $\mathrm{WHO}$ on how to prevent the spread of the virus are subject to interpretation at the state level, which results in the introduction of different strategies and measures with a varying degree of strictness. Generally, epidemiology of SARS-CoV-2 can offer in general two macroscopic strategies of action against the spread of the virus (Pueyo 2020): suppression (i.e. lockdown of whole cities like in Wuhan) and "flattening the curve" (by social distancing and contact tracing). Optimizing public health strategy can be supported by computational social sciences (Squazonni, et al. 2020) and qualitative behavioural sciences (Van Bavel et al. 2020).

Figure 1. Geography of SARS-CoV-2 epidemic. [Left] Outbreak network of the first 48 cases of COVID-19 in Poland (edge - epidemiological link, node - infected patient, coordinates and names - countries and geographical coordinates with noise, colors - date of confirmation 03-12.03). [Right] Arrival time of the first case to each voivodeship.

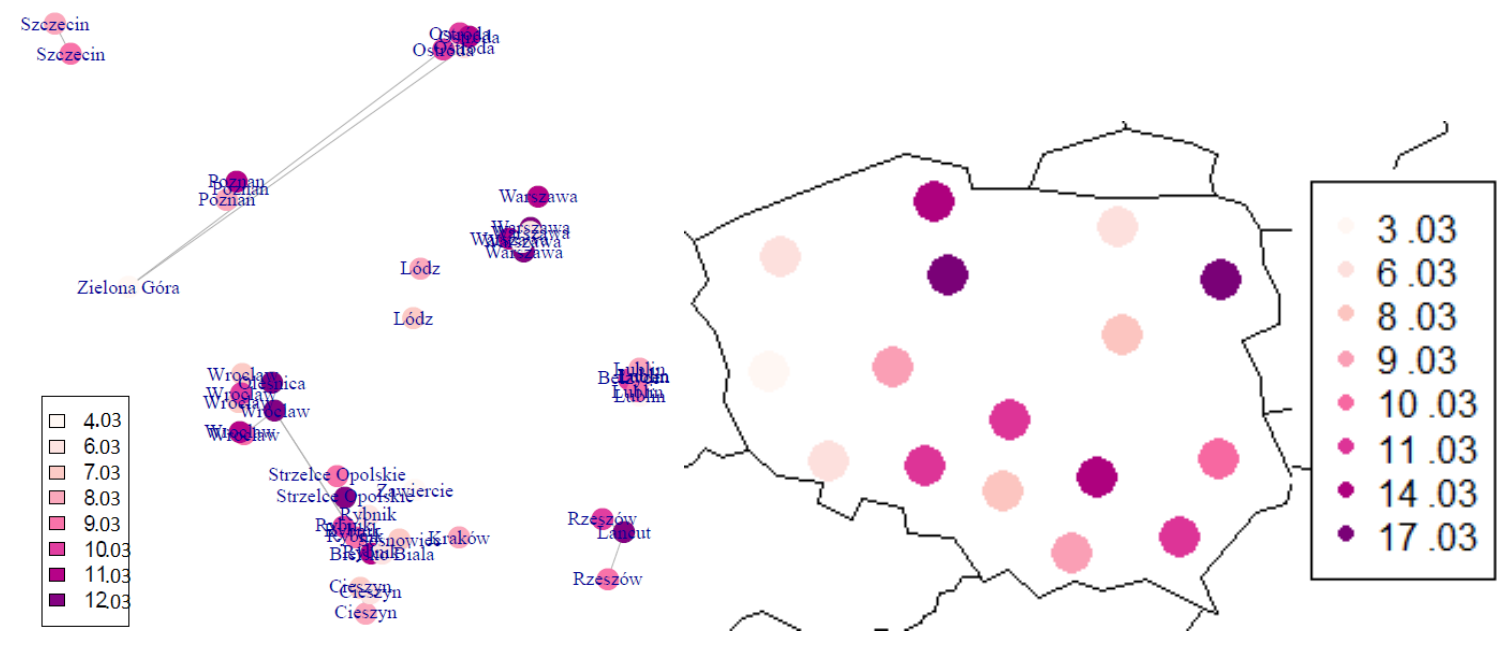

Source: Visualisation own based on Wyborcza data (2020) and ECDC (2020)

This poses an interesting question: why some states (i.e. China and South Korea) are coping with the epidemic much better than others (i.e. Italy or Iran)? There is no simple answer, as a number of complex and dynamically related variables come into play here. 
Figure 2. Projection of incidence (No. of new cases of infections) with correction by distancing and climatic coefficients (reduction of infection probability in \%) with constant intensive distancing [left] and with releasing social distancing regime after $10.05^{1}$ [right]

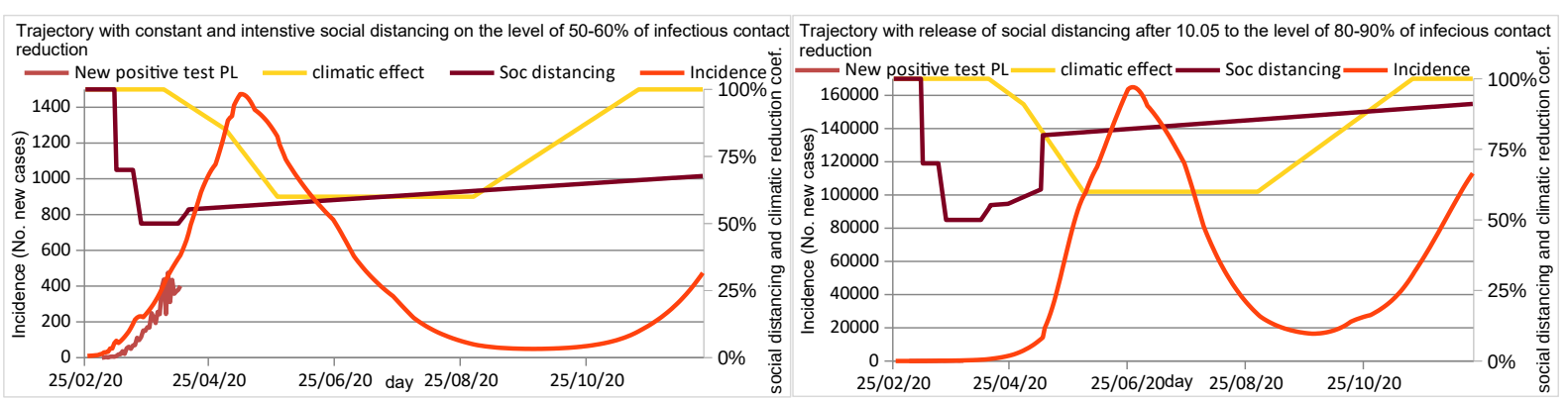

Source. Visualisation own based on data from Poland till 02.04.2020 (ECDC 2020) and parameters from (Interdisciplinary, 2020C)

Implementing radical policies (as it is happening in Poland) could be a matter of several dozen thousand [Fig. 2 left] against millions [Fig. 2 right] of infections in smaller-scale restrictions scenarios. With an already dysfunctional healthcare system struggling with lack of staff (Poland has the lowest number of physicians per capita in EU (Eurostat 2019) and OECD (OECD 2019) and 3rd lowest number of nurses per capita in EU (Eurostat 2019)) and lack of personal protective equipment, it could lead to almost a hundred thousand of additional deaths in the worst-case scenario [Fig. 2 right]. In the EU, only Sweden follows a cost-effective strategy of minimizing harms to the national economy with nationalized immunization (Folkhalsomyndigheten 2020). According to Fredrik Liljeros, a world-famous sociologist specialising in infectious diseases, "Swedish strategy is more scientifically based than anywhere else" (BCC 2020). However, Swedes are expecting that the need for Intensive Care Unit beds could exceed its current capacity by even 10 times in the peak of the epidemic (ICU Swe 2020). For this reason, they are currently building field wards and are developing ethics for triage and patient selection criteria (Folkhalsomyndigheten 2020).

\section{SOCIOLOGICAL BACKGROUND}

Sociological analysis of health issues deals with the complex relationship between mass culture and medical knowledge. For this reason, there is no direct translation between scientific evidence (e.g. the question of the effectiveness of vaccination or protective masks in infection prevention) and colloquial knowledge describing an infectious disease (Taranowicz 2010). Due to the fact that different agents perceive the risks associated with the virus differently (including scholars, who present extremely different, often unsupported opinions), perception analysis is necessary, and it con-

\footnotetext{
${ }^{1}$ Assuming a simple SEIR (Jarynowski, Grabowski 2015) model for Poland and the following parameters: incubation period: 4.5 days; infectious period / time until isolation: 6.5 days; average daily infectious contacts; 40 imported cases from abroad since 25.02; climate (weather) correction decrease of infectivity by $25 \%$ in summer, (e.g. due to the virus's susceptibility to high temperatures, different structure of physical contacts and induced immunity); social distancing is reducing contacts up to $40 \%$.
} 
stitutes the main purpose of this article. Using elements of the actor-network theory (ANT (Latour 1999)), we emphasize the essence of semiotic networks, stressing the agency of the biological viral factor affecting the behaviour of people (actors). The field, or space of potential semantic connections between meanings is expressed by representatives of various organizations, social capital or ideology. We are also interested in the way (Diani 2015) actors cooperate with each other, distribute resources or enter into conflict, drawing boundaries for each other.

The Internet covers 85\% of the total literate population in Poland (PBI 2020), encompassing most demographic categories with a small exclusion of elderly people (affinity index <80) and marginalized groups (affinity index<80). Recently, due to social distancing, most social contacts in most age categories have moved from the physical to the virtual world. As a consequence, it serves as a particularly valuable source of data on social dynamics as perception of the current situation. With the help of this source, we can investigate the following phenomena:

- interest in events related to the coronavirus in the world and in Poland;

- people's behavior towards the epidemic and each other;

- estimation of threats pertaining to virus transmission and its consequences to our country as declared by Poles;

- information needs, fears and concerns, media coverage, conflicts in the public and political sphere, the effectiveness of information campaigns;

- operation of various national (Sanitary Inspection, Ministry of Health) and regional institutions (hospitals, offices, local authorities, etc.);

- humour: the spread of memes, conspiracy theories and fake news in social networks.

The spread of information and opinions (product life cycle) can be compared to an epidemic (Coleman et al. 1957; Jarynowski et al. 2014; Jarynowski and Buda 2018). It starts with the phase of growing interest (the so-called "early adoption"), continues to the phase of general interest (the so-called "majority") to eventually lose popularity (the so-called "laggards stage"). This approach could be potentially useful in researching the dynamics of the spread of the aforementioned phenomena.

The critical aspect of the coronavirus epidemics comprises the social consequences of social isolation (voluntary quarantine). From the sociological point of view, it causes many phenomena that can have both beneficial and adverse outcomes. The \#stayathome action has put Poles in a new, unusual, unimaginable situation. In the intergenerational context, restrictions and isolation can be compared only to martial law introduced in Poland in 1981 ("the millennials are now having their own martial law” (WP 2020)). Individual and social fear has an increasingly visible face.

$1 /$ In the dimension of interpersonal communication, we transferred our "first life" to the Internet and digital communicators. This is the most crucial channel of contacts 
within non-family social networks. For citizens in quarantine, this is the only way to contact their loved ones and get emotional support. This "mediated bond" is accepted, nurtured and refreshed. Isolation will determine how much this "worse" form of communication will save relationships and businesses. Social actors who effectively used on-line communication in the past are better prepared and probably take some advantages from the situation.

2/ Isolation causes social atomization not only in physical but also in the normative dimension. The core of the problem lies in the question: How do we know what others think when we can't discreetly look at them and copy some useful solutions? When we are condemned to television or Internet authorities (which are now basically the same), the ability to create and adjust bottom-up standards (social norms) is very limited or even impossible.

3/ The third important consequence of isolation is "constrained familism". On the one hand, this concentration on current family needs is widely accepted, but on the other hand, it will not always strengthen family ties. In isolation and under the pressure of overwhelming fear (for health, work, money), conflicts, neglect and violence against the weakest family members may tend to intensify. In the context of mental health, the multiplication of social roles and their concentration in the home area may be noxious, especially in families with children or quarantined family members.

4/ Sociologists may also be interested in the fact that isolation orders may cause a specific sociological vacuum (Nowak 1979) and they may threaten the condition of civil society and democracy in Poland.

5/ Social isolation can have political consequences. The unexpected necessity of fighting with coronavirus and emerging shortages of supplies, tests and personal protective equipment have posed a threat to the presidential elections scheduled for 10.05.2020², which the presidential candidates are striving for (except for President Andrzej Duda, seeking re-election). This kind of "medicalization of politics" and political rivalry in the conditions of domestic isolation of the whole society may cause even stronger polarization of the political scene and increase the probability of social unrest. When candidates cannot participate in a fair political run for office of the President, and when citizens are forced to vote in spite of health and life danger, there is no reliable debate preceding election decisions. The medicalization of politics in the context of presidential elections may increase the probability of violating the quarantine rules, civil disobedience or the distribution of social capital in Polish society.

\section{SOCIOLINGUISTICS}

It is worth to take a look at terminology related to the virus, as well as its social reception. First of all, there is a nontrivial relationship between the official names of SARS-CoV-2 virus and the disease COVID-19 and their colloquial counterparts, such as "coronavirus" [fig. 3], also known as "corona", "virus from Wuhan" etc. A certain tension between the former and the latter type of terminology can be observed, which will definitely become the subject of interest for (socio)linguists and anthropolo-

\footnotetext{
${ }^{2}$ Possible scenario of releasing social distancing regime on 10.05 is visualized on Fig. 2 right.
} 
gists. Individuals may favour more colloquial terms since the formation of euphemistic counterparts of particular words minimizes communicative discomfort of the addressee of the message (Allan \& Burridge 1991). On the other hand, medical terms and accurate messages are linked with the trustworthiness of the source (Frewer et al. 1996).

The phrase "social distancing" (Long, 2020) has been receiving attention from academics across the fields, frequently referring to its problematic character. Anthropologists point to the fact that the term is, in fact, an oxymoron, but despite this fact, it was quickly naturalised by language users (Laszczkowski 2020). Sociology-wise, the meaning of 'social distancing' interferes with the sociological term of 'social distance' promoted by segregation of Schelling (1971). From the medical perspective, it is noticed there exist medical definitions of quarantine and isolation (Sejm, 2020). Still, the term 'social distancing' is medically blurred and could have various meanings for particular individuals. Lastly, behavioural scientists advocate the replacement of "social distancing" with "physical distancing" in order to emphasize the fact that in spite of physical isolation, there exists a possibility of maintaining social contacts through the use of technology (Bavel et al. 2020).

Moreover, the spread of rumours and misinformation (Kassan 2020) has created uncertainty and mistrust, which is affecting the effective response of responsible units. Obviously, the media are an important actor shaping public attention, with a repertoire of tools such as metaphors (e.g. medical staff are 'superheroes' and the virus is 'an enemy'), Cuisinart effect (mixing fiction with reality), conspiracy theories, etc. (Hordalska 2016). Media messages can on the one hand build national solidarity and the sense of identity, but, on the other hand, they may contribute to the promotion of nationalistic ideas, blaming for the epidemic on particular nations or races, or they can worsen internal political conflicts.

Beyond any doubt, examining understanding, feelings and attitudes towards the current COVID-19 situation will be needed. Thus, a sociolinguistic analysis could largely contribute to understanding the related phenomena, further describing the origins, dissemination, use and functions of the terminology that occurred during the epidemic (especially in the mainstream media), taking into consideration both micro(individuals, small communities) and macro (social groups, nations) scale. 
Figure 3. Concept map and relationships between concepts related to "coronavirus" and media platforms where a given term is used.

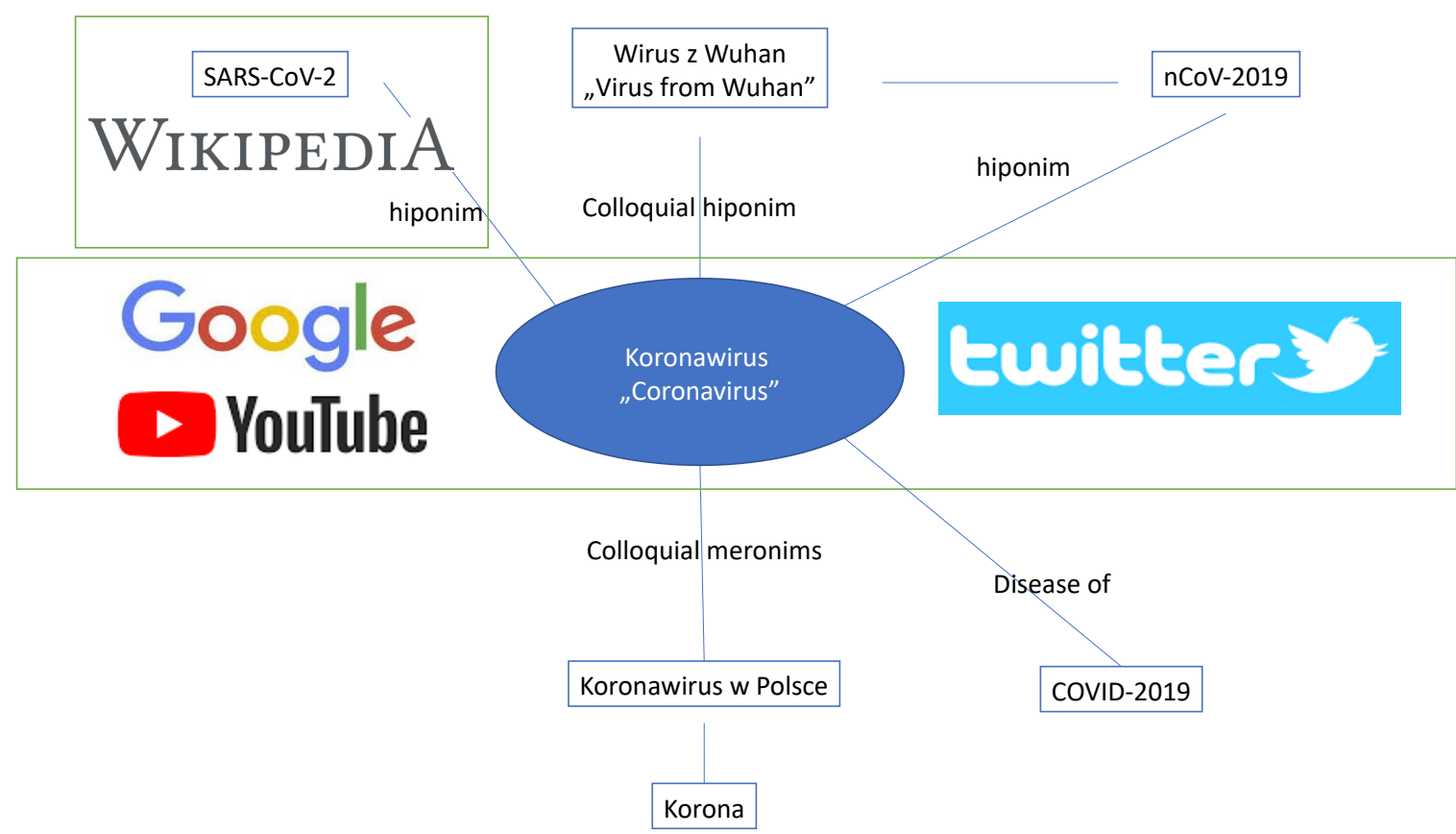

Source: Visualisation own with the use of logotypes of media platforms

\section{RISK PERCEPTION}

Risk perception is not as simple as the term used in risk assessment, i.e. value at risk (expected value of loss with a given probability of an event), but a complex socio-psychological construct with all its biases and errors (Gigererenzer, Edwards 2003). For instance, on average, people believe that adverse events like infection and death are less likely to happen to them than to others (Doliński, et al. 1987). In the previous epidemics (A/H1N1, SARS, Ebola) in the Internet era (Jarynowski and Belik 2018), societies experienced quite similar phases of interest starting with fear, then moving to practical issues such as prevention and ending with scapegoating (Gonzalez, Stanley 2014; Gałuszka 2017).

Probably, in the history of the Internet, no other phenomenon has ever received such a degree of attention as the coronavirus epidemic. In the present section, we assess the perception of SARS CoV-2 virus and COVID-2019 disease using quantitative analysis of agents and events in online media (Jarynowski et al. 2014). As far as we know, no previous studies quantitatively link the Internet activities and risk perception of infectious diseases in Poland (Samaras et al. 2020; Nuti et al. 2014). Thus the present study is still an attempt to fill this gap with a data-driven exploratory approach (without fixed hypothesis).

According to opinion polls, in late February (IBRIS 2020) less than half of Polish society ranked "koronawirus" as the most important topic, however, in mid-March, it 
was as much as 2/3 (OKO 2020) and in the end of March over 75\% of Poles (PAP 2020)

Figure 4. The daily intensity of the "Coronavirus" topic on various media platforms (15.01-30.03.2020) in Poland. Time series normalized so that 100 means maximum value for a given series.

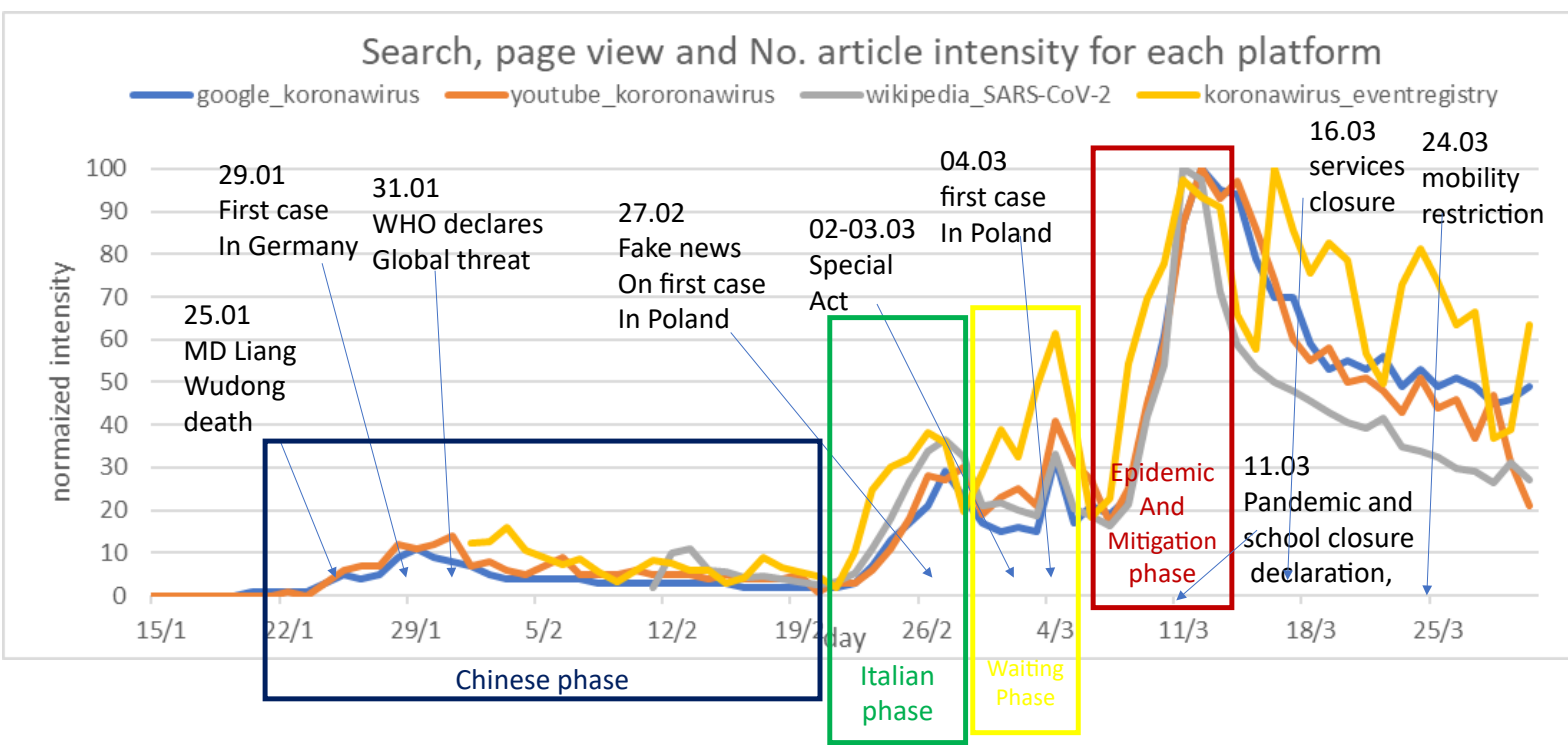

Source: visualisation own based on: google_koronawirus - queries "Koronawirus" in Polish Google by Google Trends (2020), Wikipedia_SARS-CoV-2 (Wikipedia (2020) - page views for "SARS-CoV-2" in Polish Wikipedia, youtube_koronawirus - queries "Koronawirus" in Polish YouTube by Google Trends (2020), koronawirus_eventregistry - Number of articles with keyword "koronawirus" in article body and country: Poland and language: pl in news collector EventRegsitry (2020).

"Koronawirus" was not the most important topic in Poland until the declaration of restrictions in educational institutions and border closure around March 11, 2020. Since then, attention paid to this topic in Internet media platforms has been decreasing [fig. 4] as the lifetime of the concept moves to its mature phase and gives a place to new concepts such as "Stay at home" [Fig. 5].

Another issue posited by the current situation occurs on the level of cultural fluency, as one needs to understand the government messaging concerning, for instance, social distancing [Fig. 5]. While there exist medical definitions of quarantine and isolation (Sejm, 2020), the term "social distancing" (Long 2020) is medically blurred and could have various meanings for particular individuals. Moreover, indirect messages of "trying to avoid" social gatherings may be interpreted differently, thereby putting some groups and areas at a higher risk of contagion. Therefore examining understanding of the official state decisions, as well as feelings and attitudes towards the current COVID-19 situation is necessary.

\footnotetext{
${ }^{3}$ However, each of these surveys might have been conducted according to a different methodology.
} 
Figure 5. Perception of social distancing concept via various search terms (queries): social distancing, społeczna izolacja (social isolation), redukcja kontaktów (contact reduction), zostań w domu (stay at home).

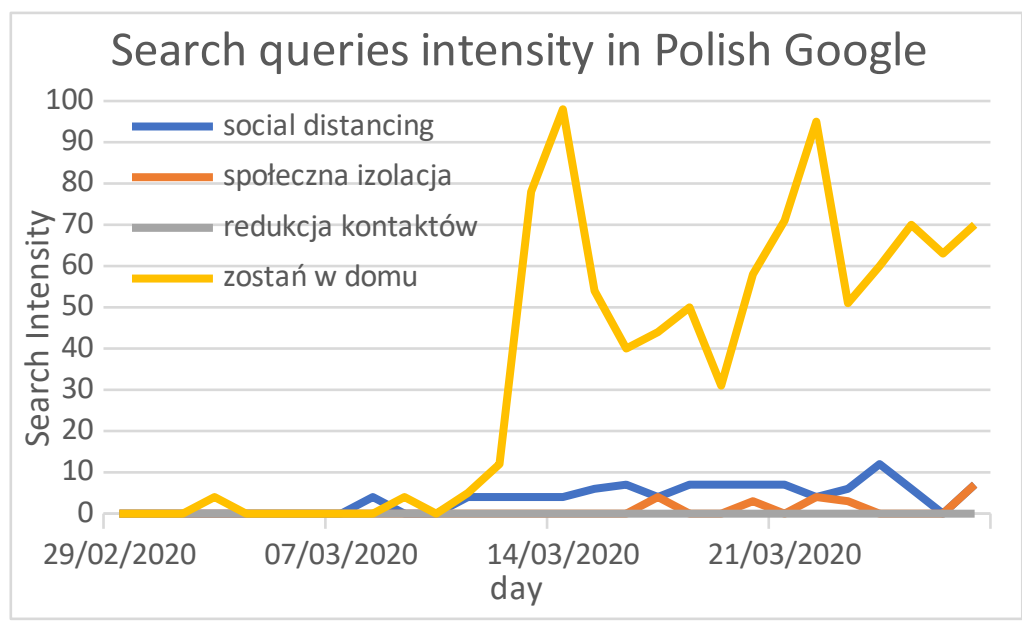

Source: Visualisation own based on Google Trends data (2020).

As far as targeting information campaigns is concerned, some interesting conclusions can be drawn from semantic networks of topics related to COVID-19 in Google. Let us consider the example of an antiviral mask [Fig. 6]. The antiviral mask is a colloquial term (there is no such medical term), and it could be related to pre-panic behaviour in situations when information needs are unsatisfied (Jarynowski, Wójta-Kempa and Belik 2020A). If a culture of fear (Furedi 2006) is high enough, people's perception of danger increases faster than the actual level of risk. On the semantic map [Fig. 6], we can see, for instance, that this kind of protection is mostly researched in the context of children. If we connect it with another observation that around 85\% of medicine-related content in Polish Internet is generated by women (Jarynowski and Belik 2018), we could conclude that targets of information campaigns should also be women. The second topic which is worth looking at is "quarantine". In this case, we can see that legal and financial aspects dominate the semantic network and medical context is not searched for (possibly due to the fact that it is not interesting to society or clear enough).

Ultimately, data analysis can also be biased due to the involvement of media platform content presenting algorithms in the discourse. In conclusion, Polish authorities, having a reliable analysis of the perception of the problem, could optimally prepare and manage the social dimension of the current epidemic and future ones. 
Figure 6. Semantic networks of topics related to COVID-19 from Google queries generated by Askthepublic. [Left] Topics related to "maseczka antywirusowa" (antiviral mask), [Right] Prepositions related to "kwarantanna" (quarantine).

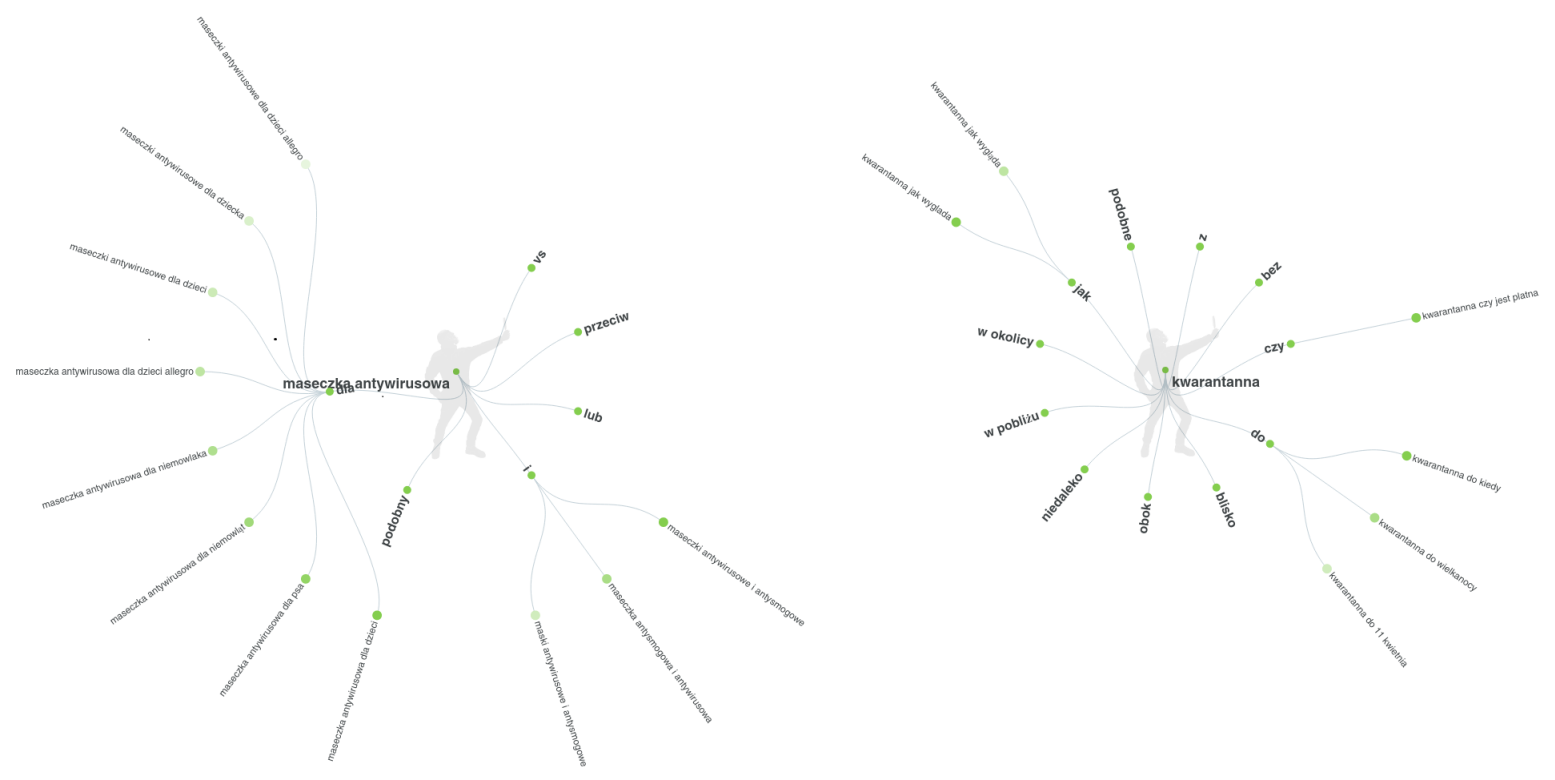

Source: Generated with Answerthepublic (2020)

\section{COMMUNICATION AND INFORMATION PROPAGATION}

We can observe an external increase in virtualization of both the Polish economy (i. e. remote working) and most categories of society (Sułkowski 2020), so information is now delivered mainly through digital channels. An interesting instance of this kind of „digital shift” can be observed in the field of education. According to UNESCO, 188 countries have implemented country-wide closures of educational institutions so far, which encompasses $91,3 \%$ of all enrolled learners (UNESCO 2020). Some countries, including Poland, are now focusing on ensuring the delivery of educational services in the form of distant learning (Gładysz and Maleńczyk 2019; Zaród 2013). However, in Poland, the digitisation process has been more developed in higher education (Maleńczyk, Gładysz and Marciniak 2019) and it is mostly at primary and secondary levels that we are now witnessing a rapid move forward. The epidemic necessitated fast implementation of this solution, which resulted in the fact that there was no debate over pragmatic issues, i.e. its cost-effectiveness in comparison to traditional education. Should the digitisation process be sustained after the pandemic is over, one could hope for a number of positive outcomes of this process. Firstly, didactic methods could be more attuned to the needs of „digital natives”, being more focused on developing students' critical thinking and ability to use the information and data available online. Secondly, we can hope for the design of more interactive textbooks and other educational resources. Lastly, digital tools could be useful to track students' progress more systematically or to control the quality of teaching.

The field which, unlike education, is not undergoing major changes, but which has a huge role to play in the current situation is the media. Social and traditional media can 
provide information and disinformation about the virus globally at an unprecedented speed, fuelling panic and creating the so-called infodemic. Infodemiology is a new field of research supporting traditional surveillance and health monitoring.

In order to observe the involvement in spreading information about coronavirus, we consider Polish Twitter an information exchange platform and analyse retweet networks. The ideas spreading from person to person in a social network (Christakis, Fowler 2007) can be analysed with phenomena such as social influence, homophily and external field (Jarynowski, et al 2014). Previous studies find that Twitter reflects the structure of the Polish political scene, and it is possible to observe a clear community structure of particular parties (Jarynowski, Wójta-Kempa and Belik 2020A). Due to filter "bubbles" observed on Twitter, public information campaigns can stay within the ruling camp and main opposition communities (Jarynowski, Wójta-Kempa, Belik 2020B).

Propaganda and persuasion techniques are widely used on the Internet easily reaching certain target groups susceptible to conspiracy theories and effectively polarizing societies (Duvanova et al. 2015). These techniques can be used by local politicians as well as by foreign intelligence (Kasprzyk 2019). There are users involved in a discussion on "koronavirus" who are potentially belonging to the group of the so-called "foreign trolls", promoting content in the buffer area between the ruling party and the mainstream opposition [Fig. 7]. In other studies, they were classified as belonging to the extreme right in the context of elections to the European Parliament (OKO 2019), or far-left in the context of African Swine Fever (Jarynowski, Płatek, Buda and Belik 2020). COVID-19 has also become part of Polish pop culture (Rudolf 2019). A creative cluster of memes is also observed in the Polish twitter network (Jarynowski, Wójta-Kempa and Belik 2020A).

As for the actual COVID-19 epidemic, theories are spreading virtually across the Internet such as: "the virus escaped from a BSL-4 class laboratory near Wuhan", or "infection can be avoided by secret therapies that the doctor will not tell you about". They fall on fertile ground, due to the script mechanism of simplifying reality, where more straightforward explanations are more easily absorbed by people (Stróżak 2010). It is especially the case since we don't know enough about COVID-19, and the recommendations and opinions of authorities such as WHO (World Health Organization), ECDC (European Centre for Disease Prevention and Control) or CDC (Centres for Disease Control and Prevention in the USA) are still revised and updated. 
Figure 7. A network of retweets with the Koronawirus hashtag in the Polish language in 28.01-11.03.2020 period (250 most central nodes according to weighted centrality, colouring according to Langevin community detection algorithm (Jarynowski et al. 2014). Yellow- ruling coalition, green - mainstream opposition, dark blue - Protestant group “Idź Pod Prąd”, light blue - Confederation party.

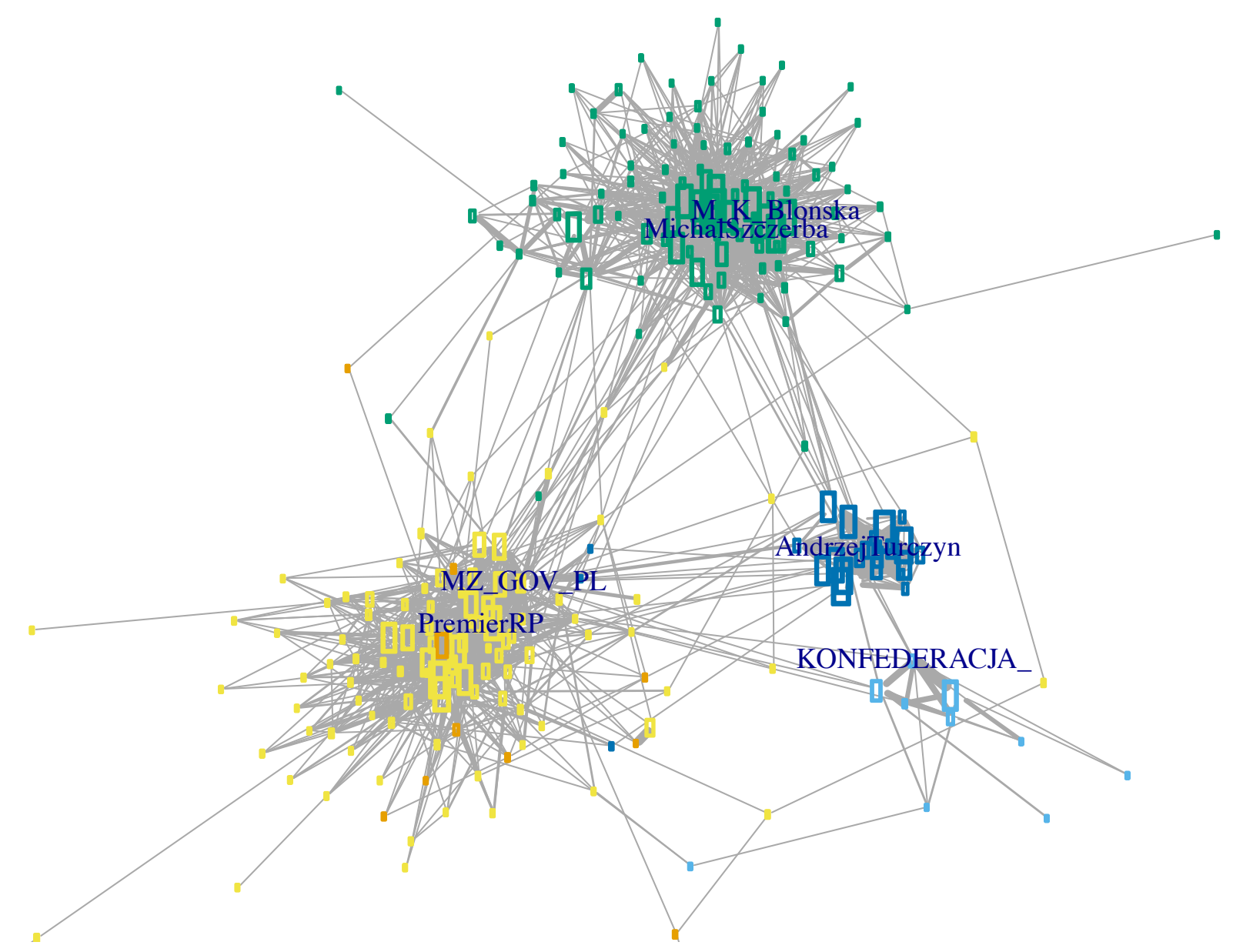

Source: Visualisation own based on Twitter data

However, social platforms in particular and the Internet, in general, cannot be considered sources of information for the whole society. In Poland, we can observe considerable digital exclusion concerning age, education or place of residence. In 2019, only $33.3 \%$ of Poles aged 65-74 are regular internet users, compared to $99.3 \%$ in the 16-24 age group. $61.1 \%$ of people with primary or lower secondary education use the Internet on a regular basis, while among people with an academic degree, this figure rises to $97.5 \%$. In big cities, this rate is as high as $86.3 \%$, while $71.4 \%$ of inhabitants of rural areas use the Internet regularly (GUS 2019B). Thus, the underprivileged groups include elderly citizens, people with primary education, and those living in rural areas. On the one hand, these groups have limited access to information produced online, which is sometimes untrue, sensationalist and panic-inducing. On the other hand, their agency in search for information is restricted - traditional media, such as television, radio and newspapers are passive in nature (McKinney et al. 2005) and in case of doubt, their users do not have access to sources to gather information from. The role of information campaigns presented in traditional media is therefore crucial. Their 
adequate frequency, structure, level of detail, as well as precise targeting, must be ensured to prevent further disease spread.

\section{POSSIBILITY OF PANIC}

We believe it is worth measuring social dynamic change with a particular focus on panic [Fig. 9] using dynamic systems approach (Jarynowski, Paradowski, Buda 2019). Researchers working on panic distinguish its various pathways as:

- cognitive (used in psychological individual person model, i.e. in bipolar disorder (Fava and Morton 2009));

- emotional (used in social psychologist model, i.e. during evacuation [Wąs and Kułakowski 2014]);

- social (used in social models, i.e. moral panic with an essential role of external field and influence of significant others [Strupiechowska 2018]).

Panic during a disease outbreak can be mainly mediated by latent variables such as (Oh et al. 2020):

- fear (e.g. fear of the unknown, or a sense of threat to oneself and loved ones);

- anger (e.g. anger at the bad condition of health care in Poland, mistakes of those in power, or adverse side effects of social distancing).

According to a survey conducted in late March (PAP 2020), there is demographic variation across Poland concerning attitudes towards coronavirus. People over the age of 55 are the most afraid of being infected ( 80\%), while people aged 18-24 are the least afraid ( $\sim 40 \%)$. Moreover, the inhabitants of larger cities (over 20,000 inhabitants) are more fearful of overcrowded hospitals and inefficient healthcare than those of small towns and villages.

The main problem we will be facing in the next few weeks in Poland is exceeding system capacity for taking care of infected patients in a serious and critical condition. Moreover, social distancing and economic lock-down may affect the integrity of people's needs. According to the bottom levels of Maslov's hierarchy of needs, lack of food (physiological need) or lack of energy supplies (safety need) are objectively very unlikely, as Poland is the 3rd food producer in EU (Eurostat 2020A) and has one of the lowest energy dependence rates in EU (Eurostat 2020B). However, subjectively these basic needs can be affected due to a shortage of other daily-use products or services happening in case of disruption of the supply chain.

Some other preliminary analyses on the Polish population [Fig. 8] suggest that processing of information about COVID-2019 can arise and elicit anxiety (Sorokowski et al. 2020; Karwowski et al. 2020). 
Figure 8. Individual based model for Structural Equation modelling - SEM (Jarynowski, Paradowski and Buda 2019) of anxiety.

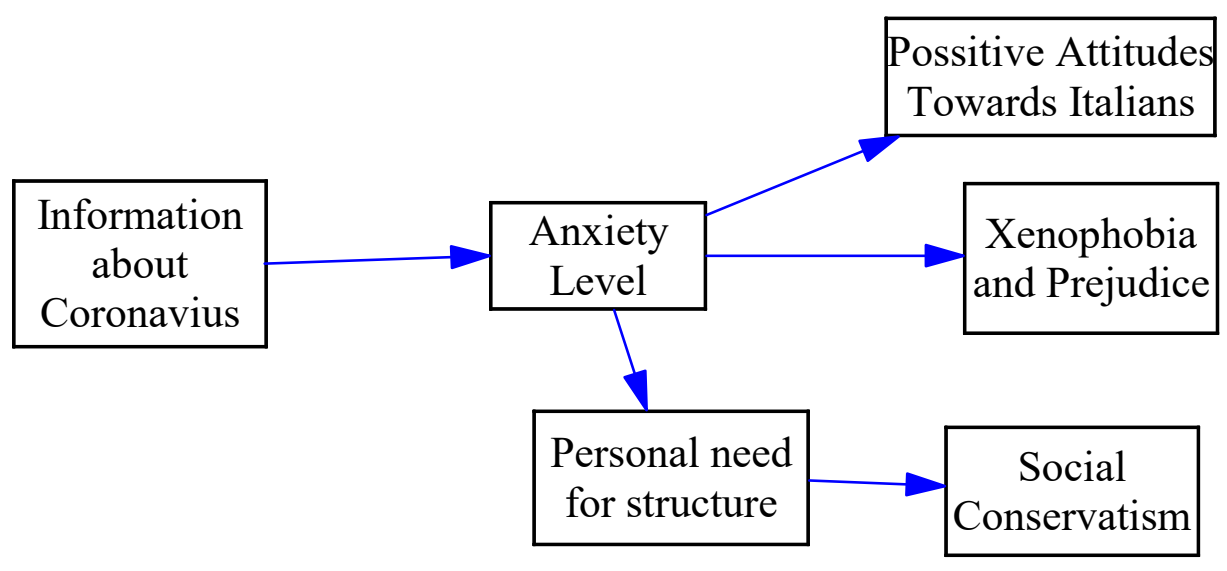

Source: adapted from (Sorokowski et al. 2020; Karwowski et al. 2020) and generated in Vensim

The main idea in System Dynamics is to draw up a set of differential equations representing social phenomena. The model (equations or diagrams) can be solved by numerical or approximative procedures, readily available in several types of computer software, such as Vensim.

We will use stocks and flows as the basic building blocks of models. We will add various types of feedback to models, close the loop and create a system whose structure determines its behaviour [Fig. 9].

Figure 9. Social based model for Causal Loop Diagram exploring the reaction of Polish society to COVID-2019 with an explicit role of external field

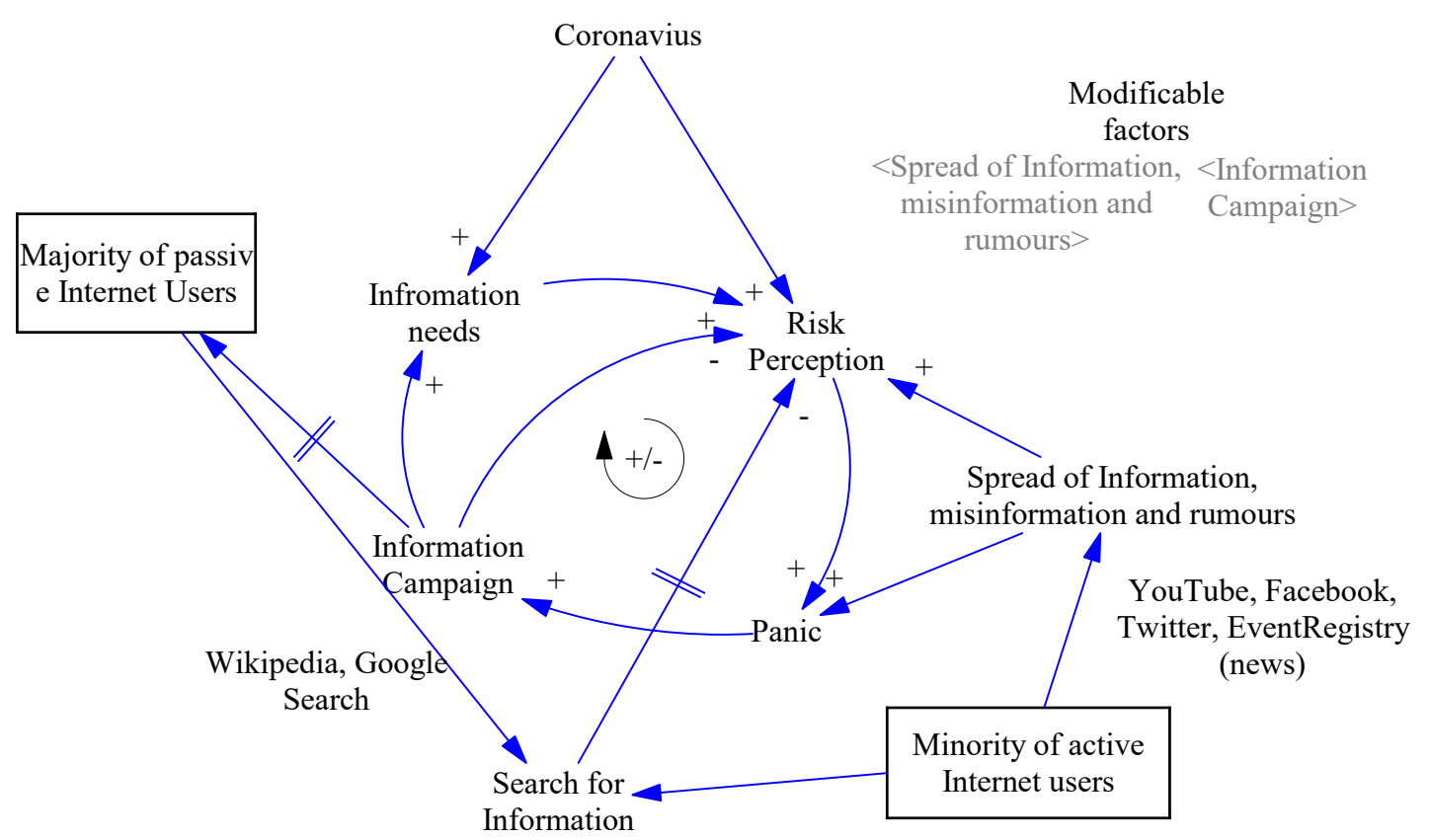

Source: Visualisation own, generated in Vensim 
Preliminary analysis of Polish media during the outbreak suggests how to control the system (at least in silico). Crisis management committee and public relations team should consider two main modifiable variables: information campaigns and spread of information, misinformation and rumors. Two categories of actors can also be distinguished (Statista 2017):

- a majority consisting of passive users seeking information on the Internet (susceptible to information campaigns);

- a minority group comprising active users generating and exchanging content (with various susceptibility to classic information campaigns).

We could recommend unconventional information campaigns for the latter (active) cohort:

- the use of influencers (commonly referred to as "influence agents" (Jarynowski, Wójta-Kempa and Belik 2020A)) to promote information;

- targeting underrepresented cohorts such as youth adults and teenagers;

- content moderation (preventive censorship - deleting posts/comments or blocking accounts).

For the majority of (passive) users, information campaigns should focus mainly on women.

Moreover, in the current epidemic, some forms of stigma (WHO 2020) and moral panic (Guardian 2020) were observed. On the Internet, this is reflected by symbolic violence and hate speech, as illustrated by the following quote from Twitter: "Chinese should be banned from entering our country".

To sum up, we are going to implement computational social science and digital epidemiology approaches (Jarynowski, Paradowski, Buda 2019) in order to provide urgently needed answers to social dynamics of phenomena such as panic during the outbreak.

\section{COLLECTIVE BEHAVIOUR AND SOCIAL MOVEMENTS}

The research on collective behaviour is preoccupied with its emphasis on the centre, central leaders, focal points, and coordination based on centralized communication through mass media or mutually held identities. According to the logic of centrality of informational distribution, central sources of information become major theatres of collective behaviours in modern cities. Centralized information may at the same time facilitate coordination of social protests (Ball 2007) against oppressive political regimes or help to regulate unwanted social phenomena such as the spread of panic during the development of the epidemic. Political legitimacy, or durability of political power, is not always a result of accurate information about the critical situation. Still, it is the product of perceptions not fully matched to material indices. Under strict control of the public information sphere, the horizon of visibility is limited and fo- 
cused. Yet, when the source of information is more diversified, local patterns of interpersonal communication become more important, and individuals start to rely on one another to gain news. One of the examples is 'antiviral masks'. The phenomenon of 'antiviral mask' trading could serve as a proxy of panic reactions. Masks price can be traced (Ceneo 2020), and it shows that a huge demand and limited supply caused a massive price surge. Masks and other means of standard hygiene such as disinfectant liquids were almost unavailable on the commodity market from the end of February until the middle of March. Despite the steep losses registered on financial markets since mid-February (WIG index lost 30\% in this period), which were caused by disruptions of the supply chain (mainly due to an outbreak in China) and price speculations, stock-prices of manufacturers of medical devices actually appreciated on the Warsaw Stock Exchange. In the investigated period there were shortages of the personal protective equipment for medical personnel around the world, representing a feedback loop with panic and media attention. Moreover, people were extensively buying food with a long expiration date.

Decentralization of information on the local level transforms the dynamics of collective behaviours. On the one hand rumours can simmer in the margins, propagate democratic ideas, but, on the other hand, they may promote unchecked epidemic information and incite risky behaviour. In both cases, political powers seek the antidote to local information propagation processes which operates on the level of the state: accurate and consistent information about the extent and nature of the threat is central to the legitimacy of the state in the face of crisis, it is an indispensable part of prediction and maintenance of the status quo.

During the epidemic crisis, the state is very much involved in risk perception and risk management (Brown 2020). Pandemic as an exogenous event which is difficult to predict is increasingly challenging scientific and decision-making authorities (Stańczyk 2019). It generates tensions between population-level common interpretations (stories of suffering individuals), epidemiological analysis, and the interest of the state (Brown 2020).

One of the collective responses of society may be anger towards the state for its potential lack of preparedness, especially if tackling the given epidemic problem is considered to be the responsibility of the state. On an individual level, the anger or disappointment with the reaction of the state to the pandemic can result in an increased need for agency combined with a feeling of responsibility for the local community. Poland is at the forefront of countries characterised with low engagement in public benefit organizations: only 20\% of adult Poles are volunteers (Tkaczuk 2007) which is below the European average (i.e. 70\% in Sweden (Mondani 2017)). However, the epidemic situation seems to be increasing social engagement of Poles through activities ranging from making protective masks to helping elderly neighbours. Facebook group "Visible Hand" (whose name refers to Polish television programme from the 1960s and 70s which aimed at developing prosocial behaviours among children and teenagers) has now more than 100000 members offering and seeking help in a variety of forms.

Decisions about a lockdown of a country may lead to negative and positive conse- 
quences resulting from both local and central information spreading. Negative economic effects are not distributed equally and small enterprises seem to be harmed the most. Since the end of March, more than 5000 new companies are suspending their operations daily in Poland (around 15 times more than usual (CEIDG 2020)). Possible consequences of the recession will have short- and long term negative impact on social relationships, educational opportunities, political attitudes, patterns of consumption and leisure (Baranowski 2017). On the other hand, the epidemic crisis offers a number of opportunities for self-organisation of society based on local information and overcoming the threat through alternative initiatives. Most of the social initiatives move to the Internet and have no political overtones, but only assume self-help. Social movements in times of crisis also act differently from protests. The continuous emergency constrains our daily lives, but also challenges our collective creativity. Individual and collective resources are focused on everyday survival. We rely more on governmental efficiency and expert opinions than our own knowledge, however, if crises have the immediate effect of concentrating power, up to and including its militarization, collective engagement may limit the capacity of governments to act merely through force.

\section{DEMOGRAPHY}

Demographic structure is an important concern in analysing the spread of the disease in both biological and sociological context, as the age structure is connected with dependent mortality (it increases with age [Worldometer 2020]) and social contact rate is connected with the probability of infection (it differs between societies). It is interesting to analyse how Polish demography could influence spread and perception of COVID-19 in comparison with other nations (i.e. Italy) which are struggling with its outbreak.

For instance, a high death toll in Italy could be a result of overrepresentation of elderly people and a high intensity of physical contact [Fig. 10]. Elderly people with low health literacy and poor digital skills are at risk of violating the outbreak control measures. They should be targeted with information campaigns conducted by family members. 
Figure 10. Age pyramid for Poland and Italy.

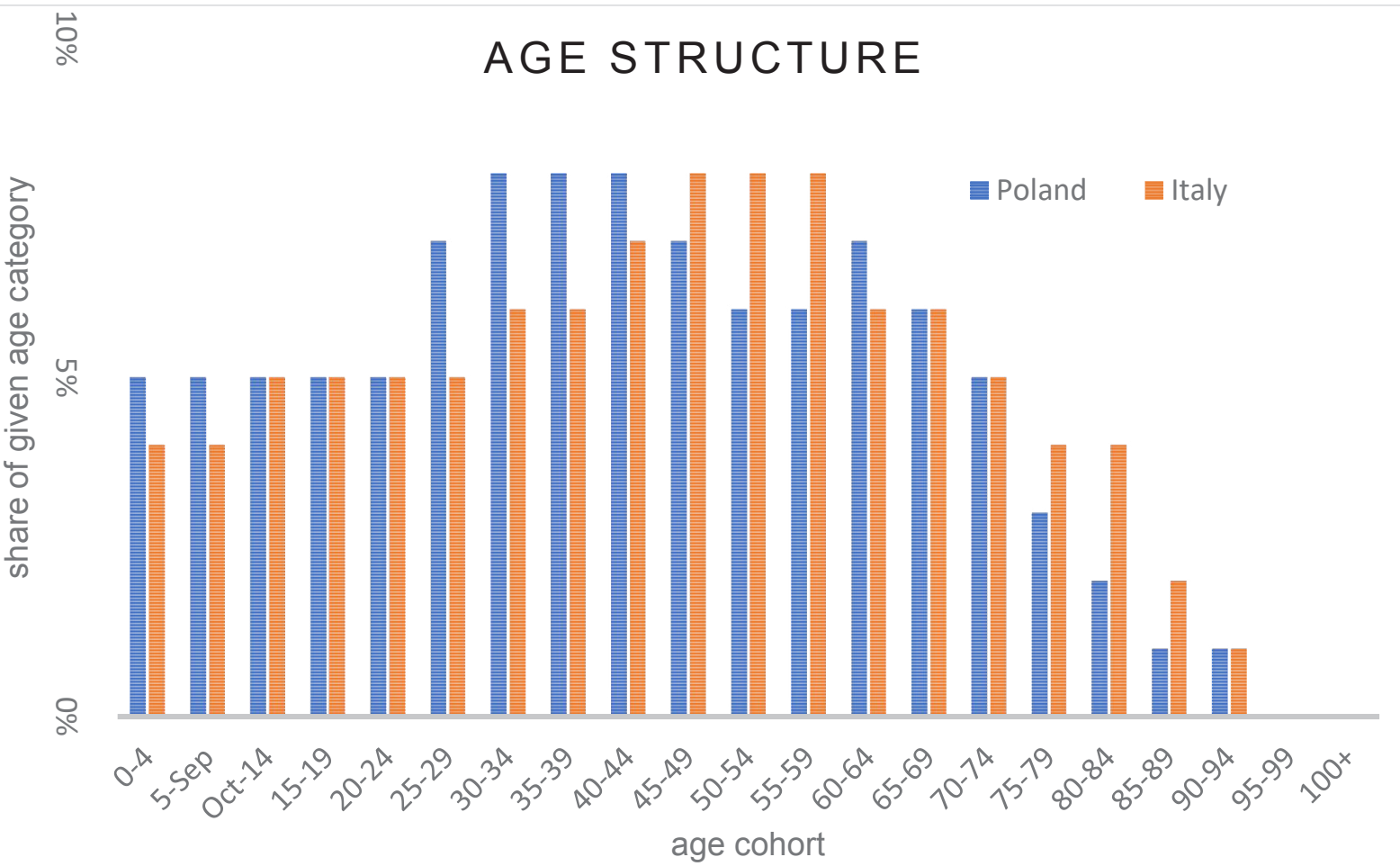

Source: Visualisation own, based on World Bank data (2020)

According to Rowe and Kahn (1997), successful ageing consists of three elements: avoiding disease, maintaining high cognitive and physical function, and continuing engagement with life. While long-term isolation concentrates on protecting the health of citizens, it may lead to a decrease of general life satisfaction due to deterioration of other aspects of life, such as self-development, independence, and social inclusion, especially in the context of the positive correlation between social interactions and life satisfaction in later life (Gow et al. 2007). It may be particularly observable in countries with a high degree of social participation of older adults, such as Italy [Fig. 11]. The fact that in Poland people over 60 are much less sociable outside their families may result not only in a lower death toll in this age group, but also in a smaller likelihood of negative repercussions of mobility restrictions, such as a major change of lifestyle or depression. Therefore, it can be stated that the problem of social exclusion of elderly people in Poland (very limited physical contact patterns with the rest of society apart from their grandchildren (Mossong, et al. 2008)) has, on average, a positive effect. Italian elderly people seem to socialize (in terms of physical contacts) just 50\% less than most active teenagers groups. In Poland elderly people have on average 5 -fold fewer contacts [Fig. 11].

Polish youths could play a role of superspreaders (Kitsak et al. 2010) due to massive numbers of contacts that they have (even higher than contacts of their Italian peers [Fig. 11]), so closing all educational institutions in the early stage of the epidemic and keeping them closed at least until summer 2020 could be the most cost-effective mitigation strategy. 
Figure 11. Age-dependent weekly physical contacts (basing on the Poland and Italy subcomponents of Polymod data, 1000 persons per country).
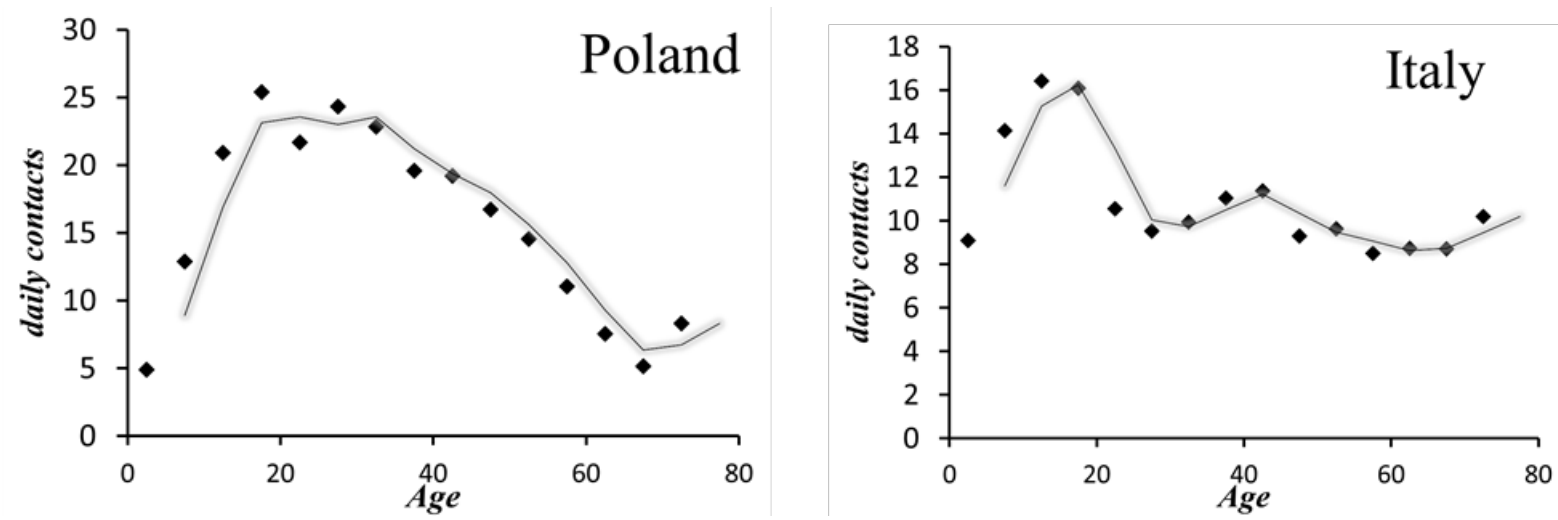

Source: Visualisation own, based on Mossong et al. (2008)

\section{CONTACT AND MOBILITY PATTERNS}

Structural properties of Polish contact patterns shown by age-age correlation and clustering (Grabowski, Jarynowski 2016; Jarynowski, Grabowski 2018) have made the landscape more complicated and Social Network Analysis (Jarynowski, Paradowski, Buda 2019) could help in making sense of it. Around 80\% of infectivity capacity (contact* contact duration [Fig. 12]) in the Polish population belongs to daily contact (household, working/schooling place, etc.) (Jarynowski and Grabowski 2018).

Figure 12. The real evolving network. Time slices of ego network in the Polish chapter of the POLYMOD study (Mossong et al 2018) with different categories of intensity and loyalty of nodes

Day $i-1$

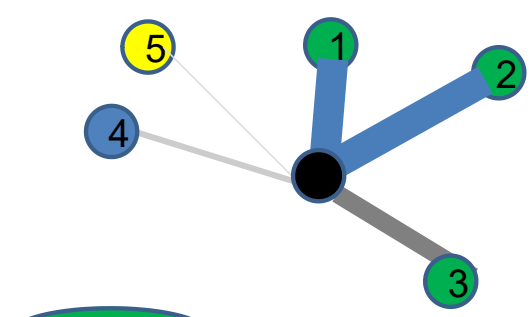

Daily

\section{Rare}

Random

Ego

Day $i$

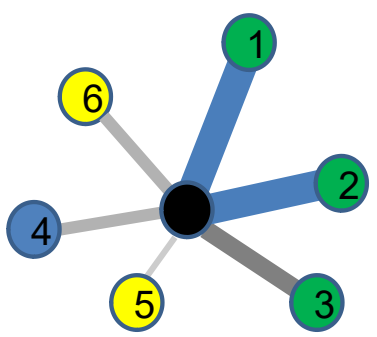

(5)

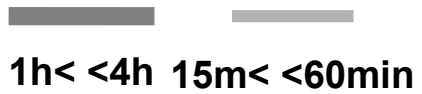

Day $i+1$

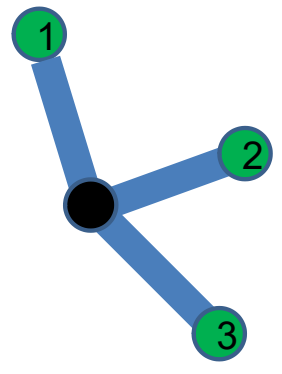

$5 \mathrm{~min}<<15 \mathrm{~min}<5 \mathrm{~min}$

Source: Adopted from Jarynowski (2017)

Poland achieved a reduction of almost 70\% in rare and random contacts (Google Mob pl 2020). However, reduction of daily contacts is difficult (workplace contacts were reduced in $30 \%$ and, i.e. in Katowice, despite the restrictions, more than $10 \%$ of population travel daily for destinations farther than $15 \mathrm{~km})$ or impossible $(15 \%$ of the increase in household contacts) (Google Mob pl 2020). These daily contacts (loyal and 
persistent links) form communities and the most efficient strategy would be to eliminate links which serve as 'bridging ties' to disconnect giant components into small disconnected networks [Fig. 13].

Figure 13. Facebook network (alter-alter) of the first author with annotated communities and possible intervention link (bridging tie).

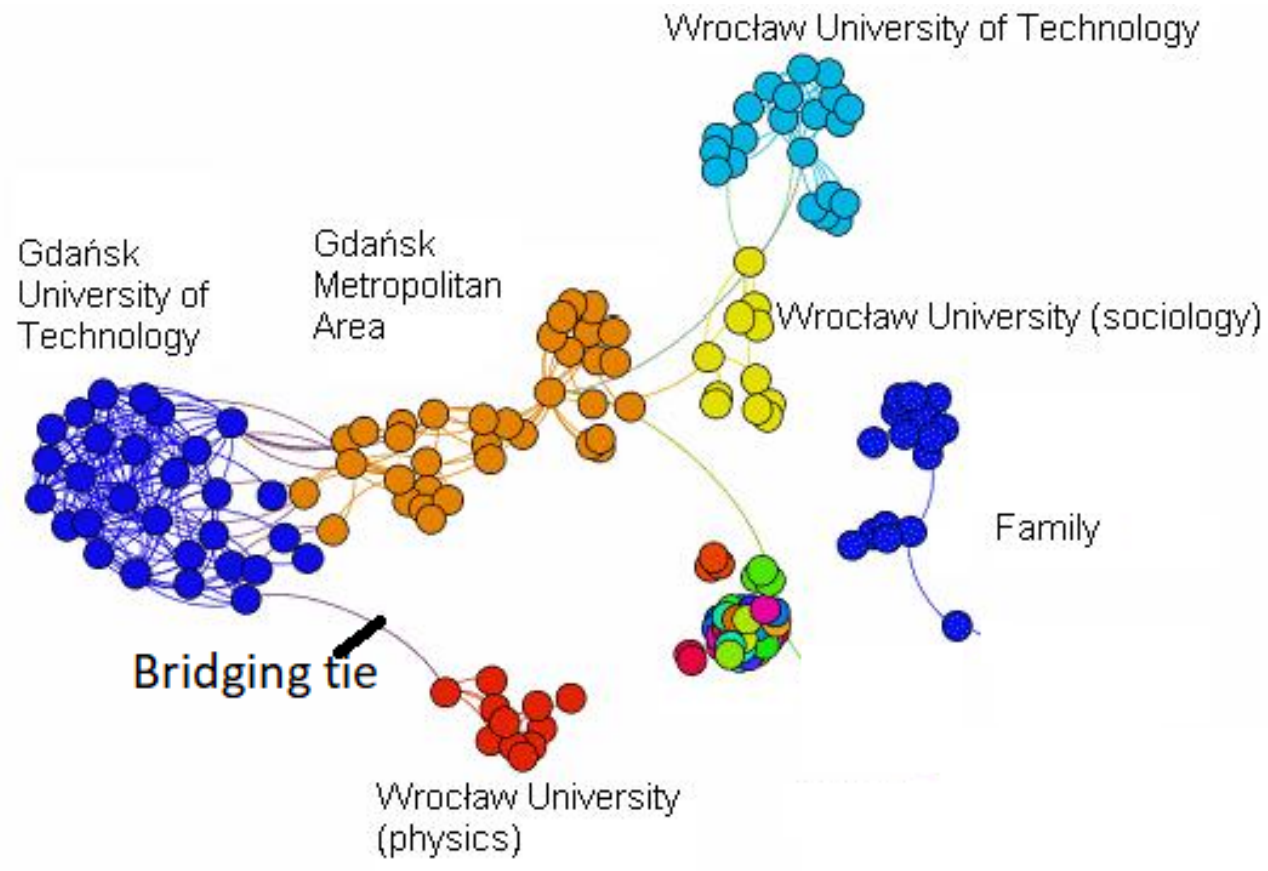

Source: Adopted from Jarynowski (2017)

Social mobility patterns can have a complicated impact on disease spread. On the one hand, a high number of Poles are often international migrants (with an important share in Northern Italy) and Poland has recently been a popular destination for immigration too, but still far from EU average (Paradowski, et al. 2020; Delhey, et al. 2019). Social distancing could accelerate the process of segregation (Fossett 2006), which is currently ongoing among non-Polish first language users (Paradowski, et al. 2020). On the other hand, Poles are a relatively poor nation and do not travel as frequently as an average European citizen (i.e. average Pole makes 5 fold less touristic trips within EU than Western Europeans, e.g. Germans (Delhey et al. 2019)), so there were much fewer returns from the epicentre of the outbreak in the first (Chinese) and second wave (Italian) of disease spread [Fig. 4]. 
Figure 14. Effective distance (Belik et al. 2011) in terms of airline passengers flows with a starting point in Wuhan.

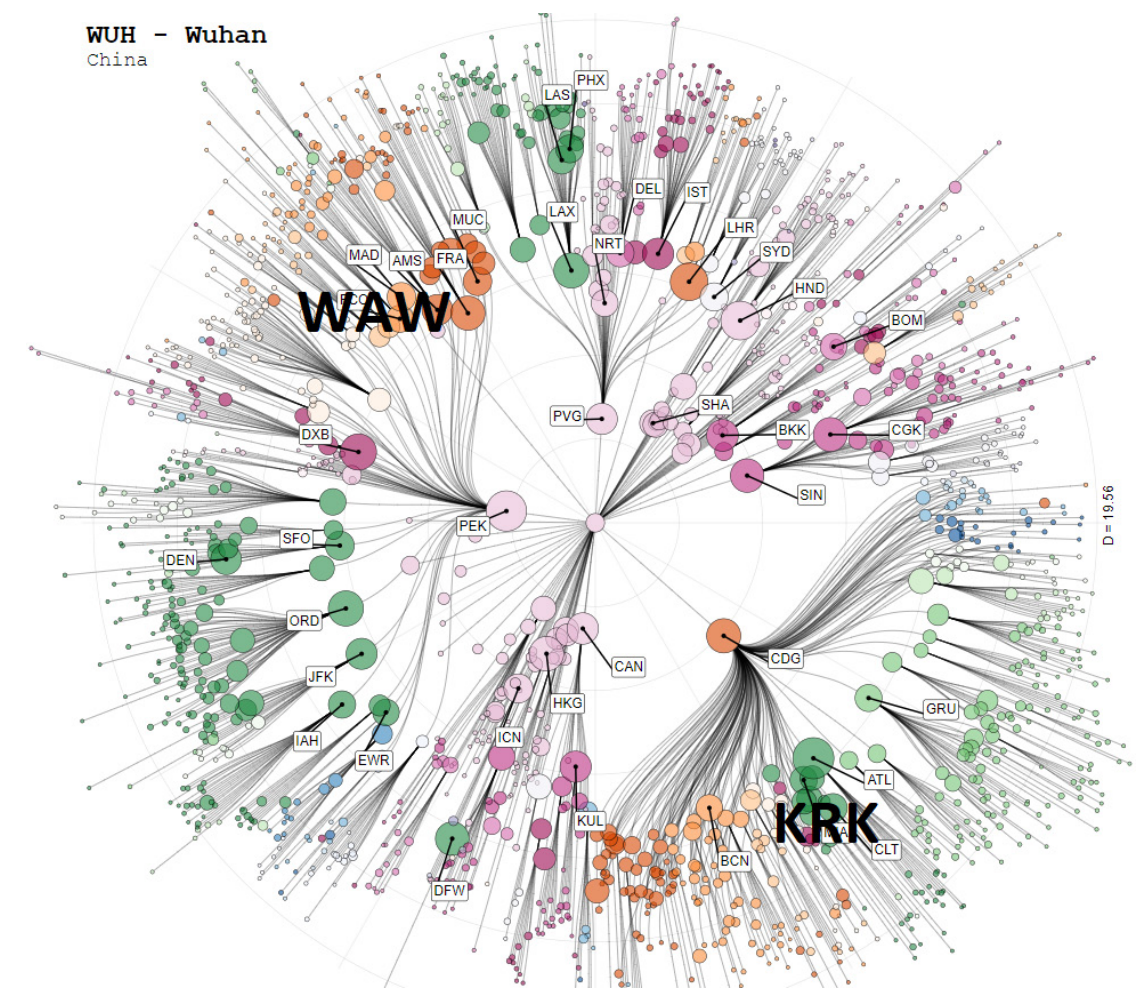

Source: Adapted from (Brockman 2020)

Such a peripheral location of Poland (among others [Fig. 14]) led to the fact that the first confirmed case of COVID-19 entered by land (in Italian phase [Fig. 4, 14 left]) rather than by air (in Chinese phase [Fig. 4]) ${ }^{4}$.

Figure 15. Mobility patterns of Poles. [Left] Mobility of Poles (mainly Polish truck drivers in mid-February). [Center] Mobility of Polish users of web pages with profiled advertising 13-27.03. [Right] Networks between residency and employer address.
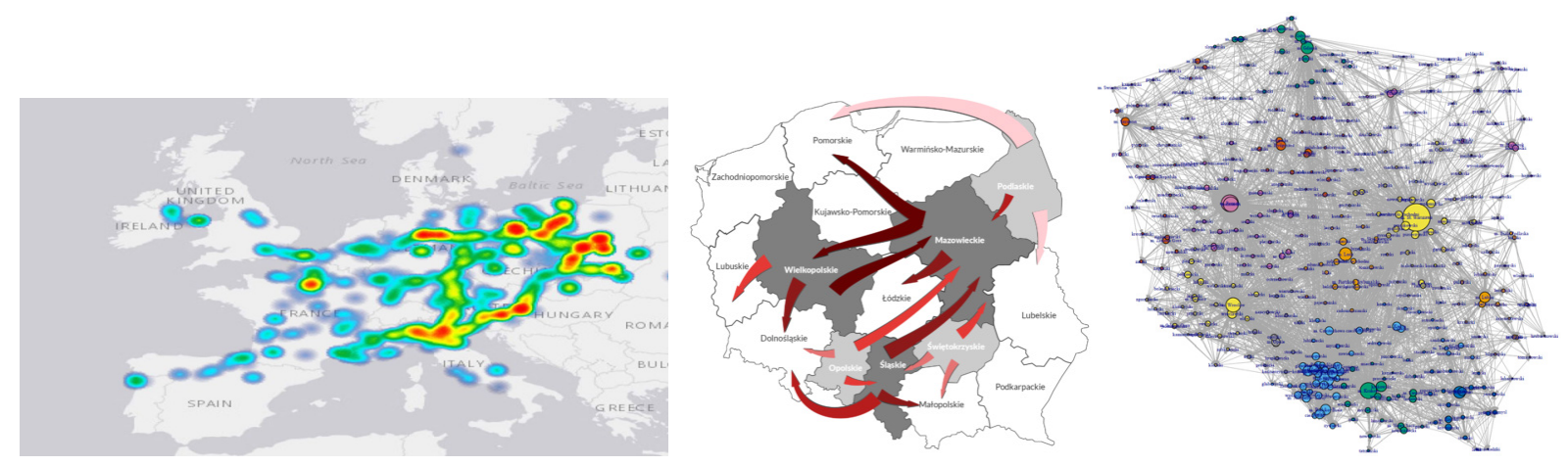

Source: [Left] Proxi.cloud (2020), [Center] Selectivv (2020), [Right] Visualisation own, based on GUS data (2019A)

\footnotetext{
${ }^{4}$ It was foreseen by the first author of the article already in January 2020 (Interdisciplinary 2020 A).
} 
Moreover, internal travel patterns are still far less intensive in Poland than in Western Europe (Pietrzak, et al. 2016). Mobility patterns (air [Fig. 14] and land [Fig. 15]) are correlated with the geographical distribution of first SARS-CoV-2 cases in Poland [Fig. 1]. Since the middle of March mobility trends have been reduced significantly, i.e. in places of recreation and retail by $78 \%$, in workplaces by $36 \%$, in transit stations by $71 \%$ (Google mob Pl 2020). It is important to mention that in the same phase of the epidemic in Lombardia, the reductions were only by $10-20 \%$ (Google mob Pl 2020).

These multi-country comparisons suggest that Poland could be coping with the epidemic somewhat better than Italy, at least from death tolls perspective.

\section{CULTURALLY RELATED NORMS AND ATTITUDES}

The COVID-19 outbreak offers an opportunity to make some proposals for comparative analysis of epidemic social outcomes in relation to social attitudes and preferred social values. Social norms are rules that prescribe what people should and should not do given their social surroundings. People are instructed by norms that tell them to keep their promises, or avoid deceiving other people. But how do norms work in a sudden change of social circumstances?

Figure 16. Conceptual Model of explanatory variables influencing Social Distancing compliance intended for SEM.

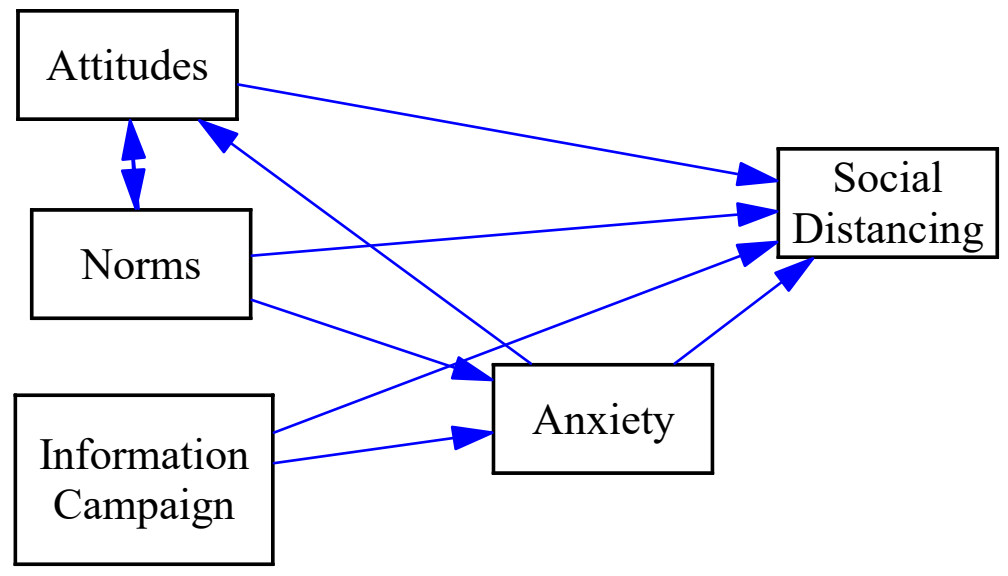

Source: Adapted from (Zhang X et al. 2020) and generated in Vensim

Society can be characterized by its specific normative responses to the crisis. The most interesting responses may appear in the context of:

normative patterns of physical contact;

adaptation of social distancing rules [Fig. 16]. 
Table 1. Simplified characteristic norms and attitudes of societies

\begin{tabular}{|c|c|c|c|c|c|}
\hline attitude & Italy & China & Iran & $\begin{array}{c}\begin{array}{c}\text { South Ko- } \\
\text { rea }\end{array} \\
\end{array}$ & Poland \\
\hline $\begin{array}{l}\text { Autonomy index. Obedience } \\
\text { vs independence. } \\
\text { \% of high and medium obedi- } \\
\text { ence in bracket (World Value } \\
\text { Survey 2005) }\end{array}$ & $\begin{array}{l}\text { low } \\
(21 \%)\end{array}$ & high (70\%) & $\begin{array}{l}\text { m e d i u m } \\
(53 \%)\end{array}$ & $\begin{array}{l}\text { very high } \\
(75 \%)\end{array}$ & $\begin{array}{l}\text { m e d i u m } \\
(44 \%)\end{array}$ \\
\hline $\begin{array}{l}\text { Trust in government and civ- } \\
\text { il services. \% of answers: "A } \\
\text { great deal" and "quite a lot" } \\
\text { (World Value Survey 2005) }\end{array}$ & $\begin{array}{l}\text { high } \\
(41 \%)\end{array}$ & $\begin{array}{l}\text { very high } \\
(75 \%)\end{array}$ & $\begin{array}{l}\text { m e d i u m } \\
(30 \%)\end{array}$ & high (63\%) & $\begin{array}{l}\text { low } \\
(16 \%)\end{array}$ \\
\hline $\begin{array}{l}\text { Importance of health. \% of } \\
\text { answers: "important" and } \\
\text { "very important" (World Value } \\
\text { Survey 2005) }\end{array}$ & $\begin{array}{l}\text { very high } \\
(97 \%)\end{array}$ & $\begin{array}{l}\text { m e d i u m } \\
(88 \%)\end{array}$ & high (94\%) & $\begin{array}{l}\text { very high } \\
(99 \%)\end{array}$ & $\begin{array}{l}\text { m e d i u m } \\
(88 \%)\end{array}$ \\
\hline $\begin{array}{l}\text { Attitude towards society. \% } \\
\text { of answers: "important" and } \\
\text { "very important" (World Value } \\
\text { Survey 2005) }\end{array}$ & $\begin{array}{l}\text { collective } \\
(43 \%)\end{array}$ & $\begin{array}{l}\text { collective } \\
(31 \%)\end{array}$ & $\begin{array}{l}\text { collective } \\
(33 \%)\end{array}$ & $\begin{array}{l}\text { semi collec- } \\
\text { tive } \\
(18 \%)\end{array}$ & $\begin{array}{l}\text { semi indi- } \\
\text { vidualistic } \\
(12 \%)\end{array}$ \\
\hline out-of home social activities & $\begin{array}{l}\text { very inten- } \\
\text { sive }\end{array}$ & intensive & intensive & moderate & moderate \\
\hline
\end{tabular}

Source: Design own, based on various sources as described ${ }^{5}$

Autonomy: the norm of autonomy is a rule which states to what extent Polish citizens are willing to comply with the norms of the society in which they live. Relative independent or anticonformists could have an impact on global opinion in whole society (Nowak et al. 1990; Nyczka, Sznajd-Weron 2013). Polish citizens seem to obey the rules if required [Tab. 1]. In comparison with Italy, Polish society has 3-fold less people who characterize themselves as fully independent. Italians are more likely (or at least they declare so) to ignore rules and refuse to sacrifice their social life against their will. However, Chinese and Korean are much more obedient than European. Asian are more likely to follow restrictions if asked. This shows that Polish citizens can be expected to follow top-down imposed rules in better compliance than Italians, but far away less adherence than Asian.

Out-of home social activities: People's lifestyle could have an impact on physical contacts and possible adaptation to social distancing rules [Tab. 1]. Polish citizens show low engagement in social activities (Tkaczuk 2006) and low rates of attendance in out-of-home services (less than $15 \%$ of the adult population regularly eat out of home [Gutkowska and Piekut 2017]). What is more, expenditure on hotels and restaurants has two times lower share in the household budget than EU average (Wołoszczyn et al. 2018), and tourism rates in Poland are low (Delhey et al. 2019). Relatively low rates of participation in a voluntary organization (Tkaczuk 2006) and lack of habits of

\footnotetext{
${ }^{5}$ Disclaimer - Some measurements are outdated and in some cases levels of variables are quite subjective due to compatibility problems.
} 
outdoor social activities and low importance of social activities for the Polish society (which is in this case similar to South Korea) could inhibit SARS-CoV-2 spread.

Trust: Polish society is characterized by a low trust (Mamzer 2008) in people and especially in public institutions [Tab. 1], probably mainly due to experiences in the post-war communist period. For instance, people who do not trust conventional medical treatment and believe in conspiracy theories are advised by Polish anti-vaccination guru to inject bleach to kill the virus (Jarynowski, Wójta-Kempa and Belik 2020A). However, in the situation of crisis people are more and more likely to accept and trust the government as they seek stability (which was already observed in Poland [Sorokowski et al. 2020]).

Importance of health: The fact that most of the Italian society appreciates health itself as a value seems to be a turning point in communication strategy in Italy [Tab. 1]. In Poland it would probably not be as effective due to much lower declarative importance of health.

Attitude towards society: Most Poles will probably not be willing to get involved in action for the common good due to their semi-individualistic (selfish) approach [Tab. 1]. All other compared societies are much more likely to cooperate for the common good. For example, there is a low interest in using surgical or cotton masks (to protect others) in Poland and most mask users prefer FPP2 or FPP3 products with a better self-protecting profile (Jarynowski, Wójta-Kempa and Belik 2020A). In a conflict between private (protect myself) and public goals (protect others), the former are winning in Poland.

Also, Polish society shares a collective memory of over 40 years of communism and Soviet occupation. 'Empty shelves' metaphor of crisis constitutes an element of collective memory, which is not the case for Western European societies. Polish society was exposed to a few crises such as martial law in 1981 and systemic transformation in 1989 , so in the collective perspective, coronavirus may be yet another crisis that the society has to overcome (actively) or endure (passively).

\section{CONCLUSIONS AND FUTURE RESEARCH DIRECTIONS}

The SARS-Cov-2 will probably cause a significant epidemic outbreak in Poland soon and its elimination might not be possible for at least a few months. The need for a rapid response requires different scientific engagement, which should be based on a somewhat simplified and quick analysis. At the same time, complex and deep approach with testing, validation and replicability should be conducted later on.

Polish context of demography, social mobility and attitudes: The main problem we will be facing in the next few weeks in Poland is exceeding system capacity for taking care of infected patients in a serious and critical condition. Characteristic features of Polish society in terms of autonomy index and out-of-home activities [Tab. 1], age-structure [Fig. 10], mobility [Fig. 15] and physical contacting patterns [Fig. 7] are probably going to inhibit the spread of the disease as well as the death toll (at least in comparison with Italy). Surprisingly, negative characteristics of Polish society, such as the social exclusion of elderly, lack of horizontal mobility and high responses to neg- 
ative stimuli (Rosinski et al. 2019) together with high obedience are rather helping in managing public health during the COVID-19 crisis.

Risk perception and panic: Public anxiety or fear (Oh et al. 2020) could lead to massive purchasing of food and protective hygienic supplies, including toilet paper. Some of the Western European societies are now witnessing empty shelves for the first time since WW2. Still, this phenomenon is a part of Polish historical/collective memory (Gołka 2009) of the Polish People's Republic. Perception bias, time-framing, coherence of information with the value could lead to a varying degree of (mis-)understanding of risk (Brown 2020). Risk perception was very low in Poland until school closure and pandemic declaration on March 11, 2020, in both the absolute measure [Fig. 2] as well as in comparison to other European countries (Widzialni 2020). In the last days of March, the awareness of basic knowledge is saturated and people are mostly waiting for news and updates. Panic can occur when people overestimate a threat or do not understand it [Fig. 9]. The more often the information about SARS-CoV-2 is repeated, the more important it will be considered.

Communication, Information and Sociolinguistics: Public understanding of 'social distancing' is connected with individual actions that can affect population health (Long 2020). Information and awareness spread patterns could be measured [Fig. 2] and might explain compliance with the measures (Jarynowski, Wojta-Kempa and Belik 2020A).

Social engineering and techniques from other areas of social sciences have already started to be applied by governments and companies. Perhaps one of the reasons China has been so successful in controlling the spread of the infection is social control. Social media like Wecht (Wang et al. 2020; Zhang et al. 2020) and all information-related aspects of life are subject to surveillance by algorithms (e.g. Social Credit). Social media can provide information and misinformation on infectious diseases (Lusawa et al. 2017) around the world - including Poland - at unprecedented speeds. Platforms committed themselves to fight the dissemination of false information about the epidemic and content that may be false. Facebook, Twitter, and Youtube added appropriate banners, and are currently either removing particular content or blocking whole accounts. It is worth to raise the ethical role of media platforms that have technical capabilities to moderate the discourse on the infection (Baranowki and Luczys 2015). This applies to traditional journalism too, which in the pursuit of luring the reader fuels sensational content (Wolska-Zogata and Wójta-Kempa 2015). In social media, one can think about preventative censorship, primarily since the new particular act would provide such an opportunity. There are many unanswered questions, such as how long the epidemic will take to finish. How can we expect the Polish public to make informed decisions about their health and social behaviours in the absence of such information? Is more information always better? Let us consider a protective mask. Surgery mask can protect the user from droplets containing the virus only for an experienced person with trained habits. There are plenty of epidemic projections for the future for Poland (Interdisciplinary 2020C). However, some effects of social paradoxes of modelled intervention have been noticed so researchers must be aware of them (self-fulfilling prophecy or self-defeating prophecy). 
Collective behaviour: Although COVID-19 might cause more disruption due to panic reactions that it entails rather than due to its actual epidemic risk, an epidemic might pose a serious challenge to the Polish healthcare system due to, e.g. lack of staff and shortage of quick diagnostic tests or personal protective equipment. However, surgical masks decrease the probability of spreading the infection. Thus, if people need to use masks, there will be no masks available on the market (while there are deficits for medical staff already). Under conditions of a market-consumer society, private goals of individuals come into conflict with responsibility for the whole society or community (Baranowski 2013). Let us also consider surveillance and monitoring analysing systems to illustrate the mobilisation of social movements (Interdisciplinary 2020B). At present, thanks to enthusiasts, we have a few straightforward analyses for Poland (e.g. aggregate data analysis and curve-fitting model [Rogalski 2020]), or modelling (e.g. [Mostowy 2020; Gonczrek and Wójcik 2020; Jasiński 2020; Interdisciplinary 2020C; Bock et al. 2020]) and we can hope for the creation of new ones during the governmental hackathon (Hackathon 2020). However, state bodies with a dedicated budget and EU funds and focal centres such as National Institute of Public Health (NIZP-PZH), or the Department of Analysis of the Ministry of Health and National Research Institutes did not provide any quantitative analysis or predictions until the end of March 2020. As we see in this example, society (mainly led by NGOs and small companies) is taking responsibility in areas where dedicated institutions are too weak to act appropriately.

Nevertheless, there are also bright sides to the outbreak. For instance, according to Andrzej Fal, president of Polish Public Health Association: "COVID-19 also has a positive aspect, which is the dissemination of knowledge of the really basic principles of prevention of infectious diseases among Poles” (Rynek Zdrowia 2020).

We also tried to show that the compilation of many phenomena needs to be explained to understand the causes and consequences of the outbreak of epidemics in every country. Practical activity within public health must be highly supported by such disciplines like epidemiology, sociology, demography or culture studies etc. Public health is primarily this kind of knowledge and practice which needs interdisciplinary cooperation with many partners to overcome the spread of SARS-CoV-2. The words of late Wojciech Sitek, mentor of several generations of sociologists in Wrocław, seem to be particularly actual nowadays: "Sociology and especially computational social science is a public service for developing better societies" (Sitek 2007). We are now witnessing the moment for a particular mobilisation of all academics to work towards an effective response to the pandemic, and we believe sociology should also be a part of it.

FUNDING: This research received no external funding.

CONFLICT OF INTEREST: The authors declare no conflict of interest.

ACKNOWLEDGEMENTS: We thank PNFN (2019-21), NCN (2016/22/E/HS2/00034), and FU Berlin (FUAvH: 08166500) for partial financial support and Vitaly Belik, Łukasz Krzowski, Ireneusz Skawina, Andrzej Buda, Piotr Szymański, Michał B. Paradowski for discussions. 


\section{REFERENCES}

Acheson Donald. 1988. Independent inquiry into inequalities in health. HM Stationary Office, London.

Allan, Keith, and Kate Burridge. 1991. Euphemism \& dysphemism: Language used as shield and weapon. New York: Oxford University Press.

AnswerPublic. 2020. “Answer the Public.” Retrieved April 05, 2020. https://answerthepublic.com

Ball, Philip. 2007. Masa krytyczna. Kraków: Insignis

Baranowski, Mariusz. 2013. "Between social control and conflict: an analytical framework for social movements." Acta Universitatis Lodziensis. Folia Sociologica 47: $5-16$.

Baranowski, Mariusz and Piotr Luczys. 2015. “Nadzorować i kształtować. Wymiary społeczeństwa sieciowego.” Człowiek i Społeczeństwo 40(2): 13-27.

Baranowski, Mariusz. 2017. “Welfare sociology in our times. How social, political, and economic uncertainties shape contemporary societies.” Przegląd Socjologiczny 66(4): 9-26. DOI: 10.26485/PS/2017/66.4/1.

BCC. 2020. "Why Sweden is taking a different path in the pandemic." Retrieved April 05, 2020 (https://www.bccourier.com/why-sweden-is-taking-a-different-pathin-the-pandemic/).

Belik, Vitaly, Theo Geisel and Dirk Brockmann, 2011. "Natural human mobility patterns and spatial spread of infectious diseases." Physical Review X 1(1): 011001.

Bicchieri, Cristina. 2006. The Grammar of Society. Cambridge: Cambridge University Press.

Bock, Wolfgang, Barbara Adamik, Marek Bawiec, Viktor Bezborodov, Marcin Bodych, Jan Pablo Burgard, Thomas Goetz et al. 2020. "Mitigation and herd immunity strategy for COVID-19 is likely to fail." medRxiv.

Brockmann, Dirk. 2020. “Analysis of the spreading path of 2019-nCoV.” Retrieved April 05, 2020 (http://rocs.hu-berlin.de/corona/).

Brown, Patrick. 2020. "Studying COVID-19 in light of critical approaches to risk and uncertainty: research pathways, conceptual tools, and some magic from Mary Douglas." Health, Risk \& Society 22(1): 1-14. DOI:10.1080/13698575.2020.17455 08

Ceneo. 2020. “Koronawirus Atakuje Sklepy.” Retrieved April 05, 2020 (https://subiektywnieofinansach.pl/koronawirus-atakuje-a-wsklepach-boom-na-maski-i-nie-tylko-w-trakcie-kompletowaniazamowienia-cena-skoczyla-czterokrotnie/).

CEIDG. 2020. ”Wnioski przetworzone przez system.” Retrieved April 05, 2020 (http:// prod.ceidg.gov.pl/ceidg.cms.engine/?D;bbd09402-098c-43a5-a8bf-e260b22f283b).

Coleman, James, Elihu Katz, and Herbert Menzel. 1957. "The diffusion of an innovation among physicians.” Sociometry 20(4): 253-270.

Christakis, Nicholas A. and James H. Fowler. 2007. “The Spread of Obesity in a Large Social Network over 32 Years.” New England Journal of Medicine 357(4): 370-379. doi:10.1056/NEJMsa066082

Delhey, Jan, Monika Verbalyte, Auke Aplowski, and Emanuel Deutschmann. 2019. 
“Network Europe: Transnational Human Activities and European Integration.” Retrieved April 05, 2020 (www.network-europe.eu).

Diani, Mario. 2015. The Cement of Civil Society. Cambridge: Cambridge University Press. Dolinski, Dariusz, Wojciech Gromski, and Ewa Zawisza. 1987. "Unrealistic pessimism.”

The Journal of Social Psychology 127(5): 511-516.

Duvanova, Dinissa, Alexander Semenov, and Alexander Nikolaev. 2015. "Do social networks bridge political divides? The analysis of VKontakte social network communication in Ukraine.” Post-Soviet Affairs 31(3): 224-249.

ECDC. 2020. "Data on the geographic distribution of COVID-19 cases worldwide." Retrieved April 05, 2020 (https://www.ecdc.europa.eu/en/publications-data/download-todays-data-geographic-distribution-covid-19-cases-worldwide).

Eurostat. 2019. “Healthcare personnel statistics.” Retrieved April 05, 2020 (https:// ec.europa.eu/eurostat/statistics-explained/pdfscache/37382.pdf).

Eurostat. 2020A. "Agricultural production.” Retrieved April 05, 2020 (https://ec.europa.eu/eurostat/statistics-explained/index.php/Agricultural_production_crops).

Eurostat. 2020B. “How dependent are we on energy?” Retrieved April 05, 2020 (https:// ec.europa.eu/eurostat/cache/infographs/energy/bloc-2c.html).

EventRegistry. 2020. “Event Registry.” Retrieved April 05, 2020 (https://www.eventregistry.org).

Eysenbach, Gunther. 2009. “Infodemiology and Infoveillance: Framework for an Emerging Set of Public Health Informatics Methods to Analyze Search, Communication and Publication Behavior on the Internet." Journal of Medical Internet Research 11(1): e11.

Fausto-Sterling, Anne. 2020. “Teach the virus”. Retrieved April 05, 2020 (https:// docs.google.com/document/d/1dTkJmhWO8NcxhmjeLp6ybT1_YOPhFLx9hZ43j1S7DjE/preview?fbclid=IwAR1P7J4SgURaz5T4IJZ3eoDtOe2xkBv-Hvt7JiF6sqSFXzqT8ih9su7UUh0).

Fava, Leonardo, and John Morton. 2009. “Causal modeling of panic disorder theories.” Clin Psychol Rev. doi:10.1016/j.cpr.2009.08.002

Folkhalsomyndigheten. 2020. Skattning av behov av slutenvårdsplatser Covid-19. Retrieved April 05, 2020 (https://www.folkhalsomyndigheten.se/contentassets/1887947af0524fd8b2c6fa71e0332a87/skattning-av-vardplatsbehov-folkhalsomyndigheten.pdf).

Fossett, Mark. 2006. "Including preference and social distance dynamics in multi-factor theories of segregation”. J Math Sociol. doi:10.1080/00222500500544151

Frewer, Lynn J. et al. 1996. "What determines trust in information about food-related risks? Underlying psychological constructs.” Risk analysis 16(4): 473-486.

Furedi, Frank. 2006. Culture of fear revisited. A\&C Black.

Gałuszka, Mieczysław. 2017. “Medykalizacja w kulturze strachu: przykład medialnej ekspozycji grypy A/H1N1.” Przegląd Socjologiczny 66(1): 53-81.

Gładysz, Bartłomiej, and Izabela Maleńczyk. 2019. “Academic E-learning in Poland Results of a Diagnostic Survey." Vice-editor: 35.

Google. 2020. “Google Trends.” Retrieved April 05, 2020 (https://trends.google.com). 
Google Mob Pl. 2020. “Mobility changes in Poland”. Retrieved April 05, 2020. https://www.gstatic.com/covid19/mobility/2020-03-29_PL_Mobility_Report_en.pdf Google Mob It. 2020. “Mobility changes in Italy.” Retrieved April 05, 2020 (https:// www.gstatic.com/covid19/mobility/2020-03-29_IT_Mobility_Report_en.pdf).

Golka, Marian. 2009. Pamięć społeczna i jej implanty. Wydawnictwo Naukowe Scholar.

Guardian. 2020. "Italian Minister Tries to Calm Coronavirus Panic and Attacks Profiteers.” Retrieved April 05, 2020 (https://www.theguardian.com/world/2020/ feb/27/italian-minister-tries-to-calm-coronavirus-panic-and-attacks-profiteers).

Gonczarek, Adam, and Marek Wójcik. 2020. ”Jak przewidzieć rozwój pandemii SARSCoV-2 w Polsce przy pomocy modeli matematycznych i uczenia maszynowego?” Retrieved April 05, 2020 (http://alphamoon.ai/blog/2020/03/25/jak-przewidziecrozwoj-pandemii-sars-cov-2-w-polsce/).

Gonsalves, Gregg, and Peter Staley. 2014. "Panic, paranoia, and public health-the aids epidemic's lessons for ebola.” New England Journal of Medicine 371(25): 23482349.

Gow, Alan J., Alison Pattie, Martha C. Whiteman, Lawrence J. Whalley, and Ian J. Deary. 2007. "Social support and successful aging. Investigating the relationships between lifetime cognitive change and life satisfaction." Journal of Individual Differences 28:103-115.

Gigerenzer, Gerd, and Adrian Edwards. 2003. “Simple tools for understanding risks: from innumeracy to insight.” British Medical Journal 327(7417): 741.

Grabowski, Andrzej, and Andrzej Jarynowski. 2016. "Rumor propagation in temporal contact network from polish polls.” In 2016 Third European Network Intelligence Conference (ENIC), pp. 85-89. IEEE.

GUS. 2019A. “Dane dojazdów do pracy za rok 2018.” Retrieved April 05, 2020 (https:// poznan.stat.gov.pl/seminaria-i-konferencje/uzytecznosc-wynikow-badania-dojazdow-do-pracy-dla-samorzadow-wojewodztwa-wielkopolskiego/).

GUS. 2019B. "Społeczeństwo informacyjne w Polsce. Wyniki badań statystycznych z lat 2015-2019.” Retrieved April 05, 2020 (https://stat.gov.pl/obszary-tematyczne/nauka-i-technika-spoleczenstwo-informacyjne/spoleczenstwo-informacyine/spoleczenstwo-informacyine-w-polsce-wyniki-badan-statystycznych-z-lat-2015-2019,1,13.html).

Gutkowska, Krystyna and Marlena Piekut. 2017. The Use of Catering Services By Poles. Warszawa: PW.

Hackaton. 2020. “Hack the Crisis: Poland.” Retrieved April 05, 2020 (https://www. hackcrisis.com).

Hodalska, Magdalena. 2016. Epidemie, mikroby i uczeni: wirusologia na łamach polskiej prasy. Kraków: Wyd. Uniwersytetu Jagiellońskiego.

IBRIS. 2020. “Koronawirus Ponad Polityką.” Retrieved April 05, 2020 (https://wiadomosci.onet.pl/tylko-w-onecie/wybory-prezydenckie-2020-sondaz-andrzej-duda-prowadzi-potrzebna-ii-tura/cmk8ssw).

ICU SWE. 2020. “COVID-19 i svensk intensivvård.” Retrieved April 05, 2020 (https:// www.icuregswe.org/data--resultat/covid-19-i-svensk-intensivvard/). 
Interdisciplinary. 2020 A. “Kiedy 2019-NCoV Trafi Do Polski?” Retrieved April 05, 2020 (http://interdisciplinary-research.eu/kiedy-2019n-cov-trafi-do-polski).

Interdisciplinary. 2020 B. "Czemu Polska jest nieprzygotowana na 'Koronawirusa'.” Retrieved April 05, 2020 (http://interdisciplinary-research.eu/czemu-polska-jest-nieprzygotowana-na-koronawirusa ).

Interdisciplinary. 2020 C. "Projekcje przyszłości rozprzestrzeniania się SARS-CoV-2.” Retrieved April 05, 2020 (http://interdisciplinary-research.eu/projekcje-przyszlosci-rozprzestrzeniania-sie-sars-cov-2).

Jarynowski, Andrzej, Andrzej Buda, and Piotr Nyczka. 2014. Obliczeniowe Nauki Społeczne w Praktyce. Głogów: WN.

Jarynowski, Andrzej, Jarosław Jankowski, and Anita Zbieg. 2015. "Natural vs Artificial Viral Spread within the Online Community." E-Methodology 2:71-78.4.

Jarynowski, Andrzej, and Andrzej Grabowski. 2015. "Modelowanie epidemiologiczne dedykowane Polsce.” Portal CZM 9(6).

Jarynowski, Andrzej. 2017. "Exploring the dynamics and the complexity of human behavior”. PhD diss., Jagiellonian University.

Jarynowski, Andrzej, and Andrzej Buda. 2018. "Exploring Arsenic Danger Awareness in the Polish Copper Basin-Simulation of Engagement in Online Networking." E-Methodology 5(5):58-71.

Jarynowski, Andrzej, and Andrzej Grabowski. 2018. "Influence of Temporal Aspects and Age-Correlations on the Process of Opinion Formation Based on Polish Contact Survey.” In International Conference on Social Informatics, pp. 118-128. Cham: Springer.

Jarynowski, Andrzej. 2019. “Cost-effectiveness analysis for HPV mitigation strategies in the Republic of Moldova based on infectious disease modelling." Economie şi Sociologie (2): 50-66.

Jarynowski, Andrzej, Michał B Paradowski, Andrzej Buda. 2019. "Modelling communities and populations: an introduction to computational social science." Stud Metodol 39:117-139.

Jarynowski, Andrzej and Vitaly Belik. 2019. “Choroby przenoszone drogą płciową w dobie Internetu i E-zdrowia-kalkulatory ryzyka.” [Sexually Transmittable Disease in Internet and E-health Era - risk calculators] Pp. 101-111 in Człowiek zalogowany. Kraków: Biblioteka Jagiellońska.

Jarynowski, Andrzej, Andrzej Buda, Daniel Platek and Vitaly Belik. 2020. “African Swine Fever Awareness in the Internet Media in Poland-exploratory review.” Accepted to E-methodology.

Jarynowski, Andrzej, Monika Wójta-Kempa, Vitaly Belik. 2020A. „Percepcja 'koronawirusa' w polskim Internecie do potwierdzenia pierwszego przypadku wirusa $\mathrm{w}$ Polsce.” Nursing and Public Health 2 (ahead of print). https://doi.org/10.17219/ pzp/120054

Jarynowski, Andrzej, Monika Wójta-Kempa, Vitaly Belik. 2020B. "Perception of emergent epidemic of COVID-2019 / SARS CoV-2 on the Polish Internet.” medRxiv 2020.03.29.20046789. https://doi.org/10.1101/2020.03.29.20046789

Jasiński, Maciej. 2020. „Prognozy rozwoju epidemii koronawirusa.” Retrieved April 
05, 2020 (http://www.fizykwyjasnia.pl/na-biezaco/prognozy-rozwoju-epidemii-koronawirusa/).

Kasprzyk, Rafał. 2019. ”Dezinformacja jako taka, a jak nie taka to jaka.” Fundacja Bezpieczna Cyberprzestrzeń. Retrieved April 05, 2020 (https://www.cybsecurity.org/ pl/infoops-czesc-2-3-dezinformacja-jakotaka-a-jak-nie-takato-jaka/).

Kassan, Natasha. 2020. "Disinformation and coronavirus.” Retrieved April 05, 2020 (https://www.lowyinstitute.org/the-interpreter/disinformation-and-coronavirus).

Karwowski, Maciej, Marta Kowal, Agata Groyecka, Michal Bialek, Izabela Lebuda, Agnieszka Sorokowska, and Piotr Sorokowski. 2020. "When in Danger, Turn Right: Covid-19 Threat Promotes Social Conservatism and Right-wing Presidential Candidates." PsyArXiv March 31. doi:10.31234/osf.io/pjfhs.

Khosravi, Moshes, 2020. "Perceived Risk of COVID-19 Pandemic: The Role of Public Worry and Trust.” Electron J Gen Med 17(4): em203.

Kitsak, Maksim, Lazaros K. Gallos, Shlomo Havlin, Fredrik Liljeros, Lev Muchnik, H. Eugene Stanley, and Hernán A. Makse. 2010. "Identification of influential spreaders in complex networks.” Nature physics 6(11): 888-893.

Laszczkowski, Mateusz. 2020. "The return of the plague spreader.” Retrieved April 05, 2020 (https://allegralaboratory.net/the-return-of-the-plague-spreader/?fbclid=IwAR2RRz4HWwOgq8rWPsz1xARMi84myqu-rNLj6RIsil3pcNpU5oqANOb$\underline{\mathrm{nmCU}}$.

Leskovec, Jure, Lada A Adamic, and Bernardo A Huberman. 2007. "The dynamics of viral marketing." ACM Transactions on the Web (TWEB) 1(1): 5.

Long, Nicholas J. 2020. "From social distancing to social containment: reimagining sociality for the coronavirus pandemic." Medicine Anthropology Theory (Submitted).

Lusawa, Aleksandra, Jarosław Pinkas, Wojciech Zgliczyński, Magda Mazurek, Waldemar Wierzba, and others. 2019. "Nieprawdziwe Informacje w Zakresie Szczepień Ochronnych Jako Wyzwanie Dla Zdrowia Publicznego.” Zdrowie Publiczne i Zarzadzanie (No. 1):40-45.

Ma, Rongyang, Zhaohua Deng, and Manli Wu. 2020. "Effect of Health Information Dissemination on Users ' Following and Clicking a Like During Novel Coronavirus Outbreak in China: Data and Content Analysis Table of Contents." JMIR Preprints Feb. 22, 2020:18368. DOI: 10.2196/preprints. 18368

Maleńczyk, Izabela, Bartłomiej Gładysz, and Stanisław Marciniak. 2019. "Wybrane aspekty ekonomiki e-learningu." e-mentor 1(78): 25-38.

Mamzer, Hanna. 2008. Zaufanie a życie społeczne. Poznań: Fundacja Humaniora. Maziarz, Marek, Maciej Piasecki, Ewa Rudnicka, Stan Szpakowicz, and Paweł Kedzia. 2016. "Plwordnet 3.0-a Comprehensive Lexical-Semantic Resource." Pp. 225968 in Proceedings of COLING 2016, the 26th International Conference on Computational Linguistics: Technical Papers.

McKinney, Mitchell S., Lynda L. Kaid, Dianne G. Bystrom, \& Diana B. Carlin, eds. 2005. Communicating politics: engaging the public in democratic life. New York: Peter Lang.

Mobirank. 2018. “Social Media Users in Poland.” Retrieved April 05, 2020 (https://mo- 
birank.pl/2018/12/04/liczba-uzytkownikow-facebooka-instagrama-i-messengera-w-polsce-11-2018/).

Mondani, Hernan. 2017. "Modeling Organizational Dynamics: Distributions, Networks, Sequences and Mechanisms." PhD diss., Department of Sociology, Stockholm University.

Mossong, Joël, Niel Hens, Mark Jit, Philippe Beutels, Kari Auranen, Rafael Mikolajczyk, Marco Massari et al. 2008. "Social contacts and mixing patterns relevant to the spread of infectious diseases." PLoS medicine 5, no. 3.

Mostowy, Rafal. 2020. "Pomiar i prognoza pandemii COVID-19 w Polsce w czasie rzeczywistym." Retrieved April 05, 2020 (https://rmostowy.github.io/covid-19/prognoza-polska/).

Nowak, Andrzej, Jacek Szamrej, and Bibb Latané. 1990. "From private attitude to public opinion: A dynamic theory of social impact.” Psychological review 97(3): 362.

Nowak, Stefan. 1979. "System wartości społeczeństwa polskiego." Studia Socjologiczne 4: $155-173$.

Nuti, Sudhakar V., Brian Wayda, Isuru Ranasinghe, Sisi Wang, Rachel P. Dreyer, Serene I. Chen, and Karthik Murugiah. 2014. "The use of google trends in health care research: a systematic review.” PloS one 9(10).

Nyczka, Piotr and Katarzyna Sznajd-Weron. 2013. "Anticonformity or independence?insights from statistical physics.” Journal of Statistical Physics 151(1-2):174-202.

Oh, Sang-Hwa, Seo Yoon Lee, and Changhyun Han. 2020. "The Effects of Social Media Use on Preventive Behaviors during Infectious Disease Outbreaks: The Mediating Role of Self-relevant Emotions and Public Risk Perception." Health Communication February 16 (online). doi:10.1080/10410236.2020.1724639

OECD. 2019. Health Care Resources. Retrieved March 31, 2020 (https://stats.oecd.org/ Index.aspx?DataSetCode=HEALTH_REAC ).

OKO. 2019. "Próba Wpłynięcia Na Wyniki Wyborów? Dwie Siatki Patriotycznych Trolli Wspierały Konfederacje.” Retrieved April 05, 2020 (https://oko.press/proba-wplyniecia-na-wyniki-wyborow-dwie-siatki-patriotycznych-trolli-wspieraly-konfederacje/ ).

OKO. 2020. ”Sondaż Ipsos o koronawirusie. Dwie trzecie widzi duże zagrożenie, ale nie panikujemy." Retrieved April 05, 2020 (https://oko.press/sondaz-ipsos-o-koronawirusie/).

PAP. 2020. "Czego w epidemii boją się Polacy?." Retrieved April 05, 2020 (https:// www.pap.pl/aktualnosci/news\%2C617376\%2Cbadanie-czego-w-epidemii-boja-sie-polacy-przepelnionej-sluzby-zdrowia).

Paradowski, Michał B, Andrzej Jarynowski, Karolina Czopek and Magdalena Jelińska. 2020 (subm). "Peer interactions and second language learning: The contributions of Social Network Analysis in Immersion/Study Abroad and Stay-at-Home environments." in Language and Mobility: Study Abroad in the Contemporary European Context, edited by R. Mitchell \& H. Tyne. Oxon: Routledge

Paul, Michael J. and Mark Dredze. 2011. "You Are What You Tweet: Analyzing Twitter for Public Health.” Fifth International AAAI Conference on Weblogs and Social Media. 
Pietrzak, Bernard, Justyna Wilk, and Mariola Chrzanowska. 2013. "Economic situation of eastern Poland and population migration movement." Metody Ilościowe w Badaniach Ekonomicznych 14(2): 148-157.

Pueyo, Tomas. 2020. "Coronavirus: The Hammer and The Dance.” Retrieved April 05, 2020 (https://medium.com/@tomaspueyo/coronavirus-the-hammer-and-thedance-be9337092b56).

PBI. 2020. “Polski Internet w Styczniu 2020.” Retrieved April 05, 2020 (http://pbi.org. pl/badanie-gemius-pbi/polski-internet-w-styczniu-2020/ ).

Proxy.coud. 2020. "Kartografia ekstremalna”. Retrieved April 05, 2020 (https://www. facebook.com/kartografiaekstremalna/posts/1307484376104076).

Ren, Shi-Yan, Rong-Ding Gao, and Ye-Lin Chen. 2020. "Fear can be more harmful than the severe acute respiratory syndrome coronavirus 2 in controlling the corona virus disease 2019 epidemic.” World J Clin cases 8(4):652-657. doi:10.12998/wjcc. v8.i4.652

Rosiński, Jerzy, Anna Różańska, Andrzej Jarynowski, and Jadwiga Wójkowska-Mach. 2019. "Factors shaping attitudes of medical staff towards acceptance of the standard precautions." International journal of environmental research and public health 16(6):1050.

Rogalski, Michał. 2020. „Koronawirus w Polsce”. Retrieved April 05, 2020 (https://docs. google.com/spreadsheets/d/1ierEhD6gcq51HAm433knjnVwey4ZE5DCnu1bW7PRG3E ).

Rowe, John W. and Robert L. Kahn. 1997. „Successful aging.” The Gerontologist 37(4): 433-440.

Rudolf, Edyta I. 2019. Od dżumy do Eboli: sposób przedstawienia wybranych chorób zaraźliwych $w$ przykładowych tekstach literatury popularnej. Pracownia Literatury i Kultury Popularnej oraz Nowych Mediów. Instytut Filologii Polskiej. Uniwersytet Wrocławski.

Rynek Zdrowia. 2020. „Jaśniejsza strona epidemii, czyli powszechny kurs elementarnej profilaktyki”. Retrieved April 05, 2020 (https://www.rynekzdrowia.pl/Polityka-zdrowotna/Jasniejsza-strona-epidemii-czyli-powszechny-kurs-elementarnej-profilaktyki,203741,14.html ).

Sejm. 2020. "Rządowy Projekt Ustawy o Szczególnych Rozwiązaniach Związanych z Zapobieganiem, Przeciwdziałaniem i Zwalczaniem COVID-19.” - druk nr 265. Retrieved April 05, 2020 (https://www.sejm.gov.pl/Sejm9.nsf/PrzebiegProc. xsp?id=016EAA75EDD551EBC125851E0077C1C2).

Selectivv. 2020. “Sytuacja podczas COVID-19 na podstawie danych z mobile.” Retrieved April 05, 2020 (https://selectivv.com/sytuacja-podczas-covid-19-na-podstawiedanych-z-mobile/ ).

Schelling, Thomas C. 1971. “Dynamic models of segregation.” Journal of mathematical sociology 1(2): 143-186.

Sitek, Wojciech. 2007. "Paradoksy prognoz socjologicznych.” in Socjologia jako służba społeczna. Kraków: Wydawnictwo Uniwersytetu Jagiellonskiego.

Sorokowski, Piotr, Agata Groyecka, Marta Kowal, Agnieszka Sorokowska, Michal Bialek, Izabela Lebuda, Przemysław Zdybek, et al. 2020. “Information About Pan- 
demic Increases Negative Attitudes Toward Foreign Groups: A Case of COVID-19 Outbreak.” PsyArXiv. March 31. doi:10.31234/osf.io/j23vt.

Sowada, Christofer. 2020. "COVID-19: Co po pandemii?” Blog Zdrowia Publicznego, red. M. Zabdyr-Jamróz, Instytut Zdrowia Publicznego UJ CM, Kraków. https://izp. wnz.cm.uj.edu.pl/pl/blog/covid-19-co-po-pandemii/

Squazzoni, Flaminio, Polhill, J. Gareth, Edmonds, Bruce, Ahrweiler, Petra, Antosz, Patrycja, Scholz, Geeske, Chappin, Émile, Borit, Melania, Verhagen, Harko, Giardini, Francesca and Gilbert, Nigel. 2020. “Computational Models That Matter During a Global Pandemic Outbreak: A Call to Action.” Journal of Artificial Societies and Social Simulation 23(2): 10. doi: 10.18564/jasss.4298

Statista. 2017. "Distribution of Active and Passive Social Media Users in Germany 2016”. Retrieved April 05, 2020 (https://www.statista.com/statistics/792357/social-media-active-passive-users-germany/ ).

Stankiewicz, Piotr. 2016. „O czym mówimy, kiedy mówimy o ryzyku? Społeczna percepcja ryzyka przy kontrowersyjnych inwestycjach energetycznych.” Energetyka-Społeczeństwo-Polityka 4(2): 61-82.

Strupiechowska, Monika. 2018. “Media Jako Katalizator Społecznych Lęków. Przypadek Paniki Moralnej.” Media i Społeczeństwo 8: 139-50.

Stróżak, Paweł. 2020. "Wpływ skryptu i sugestii na powstawanie fałszywych rozpoznań". Przegląd Psychologiczny 53(4):463-478.

Taranowicz, Iwona. 2010. Zdrowie i Sposoby Radzenia Sobie z Jego Zagrożeniami. Analiza Socjologiczna. Wrocław: Oficyna Wydawnicza Arboretum.

Tkaczuk, Marek. 2007. ”Rozwój organizacji społecznych w Polsce w kontekście zmian w środowisku ich działania." Annales Universitatis Mariae Curie-Skłodowska. Sectio H. Oeconomia 41:135-148.

UNESCO. 2020. “Covid-19 impact on education.” Retrieved April 05, 2020 (https:// en.unesco.org/covid19/educationresponse/).

Wang, Wenjun, Yikai Wang, Xin Zhang, Yaping Li, Xiaoli Jia, and Shuangsuo Dang. 2020. "WeChat, a Chinese Social Media, May Early Detect the SARS-CoV-2 Outbreak in 2019." MedRxiv. https://doi.org/10.1101/2020.02.24.20026682

Wąs, Jarosław and Krzysztof Kułakowski. 2014. "Social groups in crowd.” in Encyclopedia of social network analysis and mining, edited by R. Alhajj and Jon Rokne. Springer Publishing Company.

WHO. 2020. "Social Stigma associated with COVID-19." Retrieved April 05, 2020 (https://www.who.int/docs/default-source/coronaviruse/covid19-stigma-guide. pdf ).

Widzialni. 2020. “Marketing Wirusowy Koronawirusowa.” Retrieved April 05, 2020 (https://www.widzialni.pl/blog/marketing-wirusowy-koronawirusa/ ).

Wikipedia. 2020. “SARS-CoV-2.” Retrieved April 05, 2020 (https://pl.wikipedia.org/ wiki/SARS-CoV-2 ).

Wyborcza. 2020. „Koronawirus w Polsce.” Retrieved April 05, 2020 (https://biqdata.wyborcza.pl/biqdata/7,159116,25755719, koronawirus-w-polsce-europie-i-na-swiecie-mapy.html ).

Wolska-Zogata, Iwona, and Monika Wójta-Kempa. 2015. „Między rynkiem a odpow- 
iedzialnością społeczną mediów - analiza wybranych magazynów o zdrowiu.” Zeszyty Prasoznawcze 5;2(222): 347-364

Wołoszyn, Andrzej, Karolina Ratajczak, and Joanna Stanisławska. 2018. „Wydatki na usługi hotelarskie i gastronomiczne oraz ich determinanty w gospodarstwach domowych w Polsce." Studia Oeconomica Posnaniensia 6(10): 93-110.

World Bank. 2020. “World Bank Open Data”. Retrieved April 05, 2020 (https://data. worldbank.org ).

World Value Survey. 2005. “World Value Survey Data.” Retrieved April 05, 2020 (http:// www.worldvaluessurvey.org/WVSOnline.jsp ).

Worldmeter. 2020. “COVID-19 CORONAVIRUS OUTBREAK.” Retrieved April 05, 2020 (https://www.worldometers.info/coronavirus/).

WP. 2020. “My, millenialsi. W końcu mamy swój 'stan wojenny'." Retrieved April 05, 2020 (https://opinie.wp.pl/my-millenialsi-w-koncu-mamy-swoj-stan-wojenny-6490965619693697a ).

Van Bavel, Jay J., Paulo Boggio, Valerio Capraro, Aleksandra Cichocka, Mina Cikara, Molly Crockett, Alia Crum, et al. 2020. "Using Social and Behavioural Science to Support COVID-19 Pandemic Response." PsyArXiv. March 24. doi:10.31234/osf. io $/ \mathrm{y} 38 \mathrm{~m} 9$.

Youtube. 2020. “Koronawirus.” Retrieved April 05, 2020 (https://www.youtube.com).

Zaród, Marcin. 2013. "Wirtualna politechnika Otwarte kursy internetowe w edukacji przyrodniczo-technicznej.” Edukacja Biologiczna i Środowiskowa 1: 31-41.

Zhang, Jun, Weili Wu, Xin Zhao, and Wei Zhang. 2020. "Recommended psychological crisis intervention response to the 2019 novel coronavirus pneumonia outbreak in China: a model of West China Hospital”. Precision Clinical Medicine 3(1): 3-8.

Zhang, Xiaojun, Fanfan Wang, Changwen Zhu, and Zhiqiang Wang. 2020. "Willingness to Self-Isolate When Facing a Pandemic Risk: Model, Empirical Test, and Policy Recommendations." International Journal of Environmental Research and Public Health 17(1): 197. 


\section{BIOGRAPHICAL NOTE}

Andrzej Jarynowski. An expert in infection disease modelling and specialist in epidemiology from Wrocław with media coverage in Bloomberg and Reuters among others. Awarded as promising young computational epidemiologist from Eastern Europe by IPVS and as innovator in infectious disease control by IDS, both in 2018.

Monika Wójta-Kempa. An expert in public health with a sociological background. Chief of Medical Sociology Department at Wroclaw Medical University.

Daniel Płatek. An expert in social movements with a sociological background from Cracow working at Polish Academy of Sciences, Institute of Political Studies in Warsaw.

Karolina Czopek. An expert in andragogy, PhD student from Warsaw working on linguistic processes at social networks.

OPEN ACCESS: This article is distributed under the terms of the Creative Commons Attribution Non-commercial License (CC BY-NC 4.0) which permits any non-commercial use, and reproduction in any medium, provided the original author(s) and source are credited.

ARTICLE HISTORY: Received 2020-04-05 / Accepted 2020-04-10 